\title{
Pesticides and earthworms. A review
}

\author{
Céline Pelosi • Sébastien Barot • Yvan Capowiez • \\ Mickaël Hedde • Franck Vandenbulcke
}

Accepted: 2 April 2013 / Published online: 16 May 2013

(C) The Author(s) 2013. This article is published with open access at Springerlink.com

\begin{abstract}
Earthworms provide key soil functions that favour many positive ecosystem services. These services are important for agroecosystem sustainability but can be degraded by intensive cultural practices such as use of pesticides. Many literature reports have investigated the effect of pesticides on earthworms. Here, we review those reports to assess the relevance of the indicators of earthworm response to pesticides, to assess their sensitivity to pesticides, and to highlight the remaining knowledge gaps. We focus on European earthworm species and products authorised in Europe, excluding natural compounds and metals. We consider different organisation levels: the infra-individual level (gene expression and physiology), the individual and population levels (life-history traits, population density and behaviour) and the community level: community biomass and density. Our analysis shows that earthworms are impacted by pesticides at all organisation levels. For example, pesticides disrupt enzymatic activities, increase individual mortality, decrease fecundity and growth, change individual behaviour such as feeding rate and decrease the overall community biomass and density.
\end{abstract}

C. Pelosi $(\bowtie) \cdot$ M. Hedde

INRA, UR251 PESSAC, Bâtiment 6, RD 10,

78026 Versailles Cedex, France

e-mail: celine.pelosi@versailles.inra.fr

S. Barot

IRD, UMR7618 Bioemco, 75230 Paris Cedex 05, France

Y. Capowiez

INRA, UMR406 UAPV, 84914 Avignon Cedex 9, France

F. Vandenbulcke

Université Lille Nord de France-Lille 1, 59000 Lille, France

F. Vandenbulcke

LGCgE-Lille 1EA4515, Equipe Ecotoxicologie, 59650 Villeneuve

d'Ascq, France
Insecticides and fungicides are the most toxic pesticides impacting survival and reproduction, respectively.

Keywords Lumbricidae $\cdot$ Organisation levels $\cdot$ Plant protection products $\cdot$ Biomarkers $\cdot$ Insecticides $\cdot$ Fungicides · Herbicides

\section{Contents}

1. Introduction

2. Effects of pesticides at different organisation levels

2.1. Response at infra-individual level

2.1.1. Literature review

2.1.2. Indicators at infra-individual level

2.1.3. Effect of pesticides at infra-individual level

2.2. Response at individual and population levels

2.2.1. Literature review

2.2.2. Indicators and effects at individual and population levels

2.2.2.1. Life history traits

2.2.2.2. Behavior

2.3. Response at community level

2.3.1. Literature review, data extraction and analysis

2.3.2. Effect of pesticides at community level

2.4. Synthesis

3. Sources of variability in earthworm response to pesticides

3.1. Biological models

3.2. Physico-chemical conditions and duration of exposure

4. Knowledge gaps

4.1. Representativeness

4.2. Difficulties in scaling up from infra-individual to community levels

4.3. Difficulties in scaling up from laboratory to field

5. Conclusion 


\section{Introduction}

Intensification of agricultural practices and especially the use of pesticides (Fig. 1) often result in a loss of biodiversity (Hole et al. 2005), but the effects of pesticides on different taxa and especially on soil organisms are still not very clear. The present review focuses on earthworms because they represent a large fraction of soil living biomass in many temperate ecosystems and play an important role in soil functioning. As ecosystem engineers (Jones et al. 1994), they influence organic matter dynamics, soil structure (Fig. 2a, b) and microbial community (Edwards and Bohlen 1996; Fragoso et al. 1997; Sims and Gerard 1999). They actively participate in soil aeration, water infiltration and mixture of soil horizons, and they represent an important source of food for many other organisms like birds or moles (Fig. 2c, d) (Edwards and Bohlen 1996; Lavelle et al. 2006). As early as 1984, Callahan (1984) underlined the importance of earthworms for assessing the general impact of pollution in soil. Since then, earthworms have sometimes been used as bioindicators for soil quality and the environmental impacts of cropping systems and pollutants (Cortet et al. 1999; Paoletti 1999). Many earthworm species are easy to collect and to identify; some are easily bred (Lowe and Butt 2005; Yasmin and D'Souza 2007), so they have been adopted by the international community as sentinel species for the study of the environmental impact (Ecological Risk Assessment (ERA)) of anthropogenic contaminants, such as pesticides, hydrocarbons and metal trace elements (Edwards and Bohlen 1996; Greig-Smith 1992; Kautenburger 2006; Piearce et al. 2002; Seeber et al. 2005; Spurgeon et al. 2003). For instance, mortality and/or reproduction of Eisenia fetida are currently used to assess the effects of pesticides under laboratory conditions before marketing authorisation (ISO 11268-1 1993; ISO 11268-2 1998; OECD
207 1984). Often, after marketing authorisation, pesticides are no longer subject to any further evaluation by the national agencies that authorised their use. Yet in cultivated fields, non-target organisms, such as earthworms are exposed to frequent and different (e.g. insecticide, fungicide and herbicide) pesticide applications. Because of the major role they play in soil functioning, the effects of pesticides on these soil organisms should be investigated further.

Most published ecotoxicological studies on earthworms have focused on metals (Lowe and Butt 2007) while the effects of pesticides have been less studied. To date, almost 400 substances or plant protection products, also called pesticides, are authorised in Europe, including natural compounds and metals. In the scientific literature, most studies on the effects of pesticides on earthworms were made in the 1980s. Some are more recent but focus on compounds that are no longer permitted in Europe. This is the case with many studies on carbofuran (Anton et al. 1993; Ruppel and Laughlin 1977), benomyl (Stringer and Wright 1976; Wright 1977; Wright and Stringer 1973), carbaryl (Neuhauser and Callahan 1990; Tu et al. 2011), dieldrin and dichlorodiphenyltrichloroethane (Davis 1971). In Lee (1985), which is one of the major text books on earthworm biology and ecology, a review of pesticide effects on earthworms was presented. Only 13 substances out of the 84 presented are still authorised in Europe. In the same way, in Edwards and Bohlen's (1996) book, only 43 substances out of 181 are still used in Europe. For 21 of these 43, the results are insufficient to exclude adverse effects. Similarly, reviews on the effects of pesticides on soil invertebrates in the laboratory or in the field (Càceres et al. 2010; Frampton et al. 2006; Jänsch et al. 2006; Robert and Dorough 1985; Yasmin and D'Souza 2010) describe the effects of many substances that are no longer used in Europe. Recently, Tu et al. (2011) showed that 'older pesticides [...] had greater

Fig. 1 Pesticide application in a field

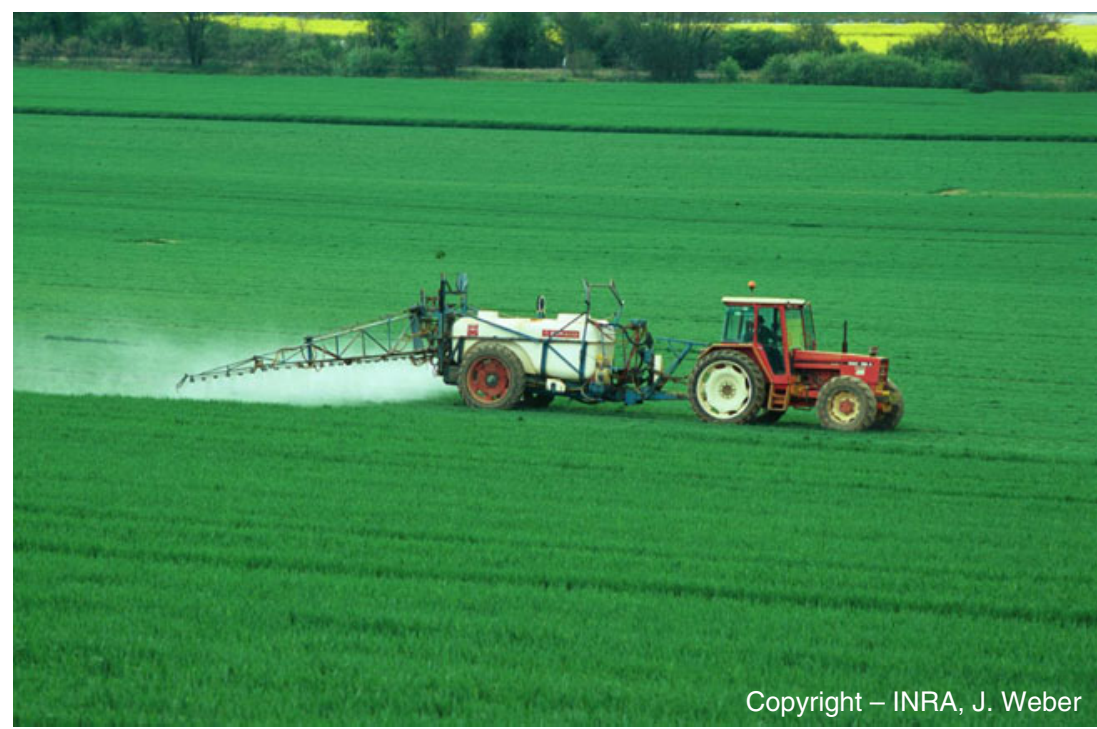


Fig. 2 Pictures showing some of the roles of earthworms in soil structure $(\mathbf{a}, \mathbf{b})$ and as a trophic resource for other organisms (c, d)
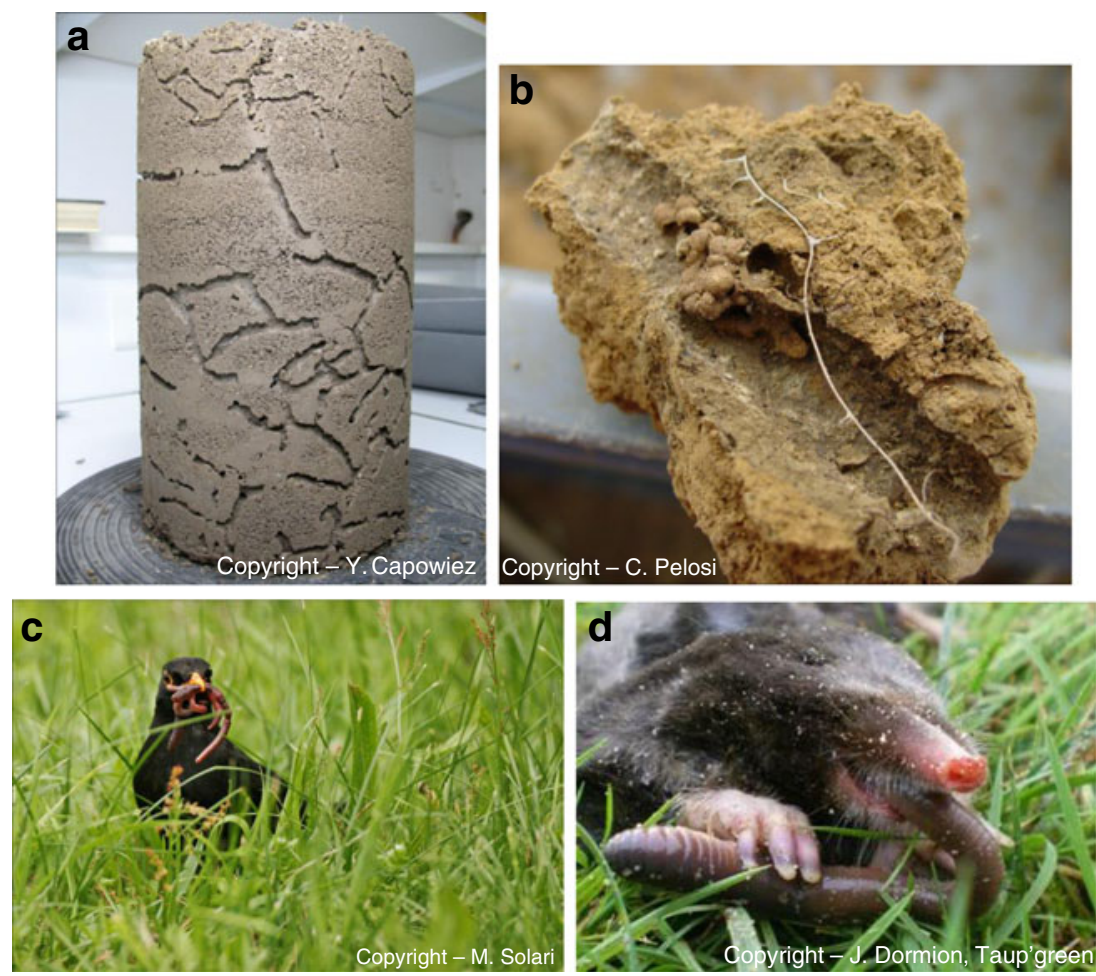

inhibitory effects on earthworms than the newer ones' and reported that 'newer pesticides are generally less toxic to nontarget organisms (e.g. earthworms) because of their relatively higher selectiveness (Casida and Quistad 1998)'. However, since there is no comprehensive study summarising the effects of currently used pesticides on earthworms in European cultivated fields, it is necessary to recap the knowledge and information available on this subject.

Studies found in the literature on the effect of pesticides on earthworms were conducted either under laboratory conditions (Bauer and Römbke 1997; Cathey 1982; RodriguezCastellanos and Sanchez-Hernandez 2007; Brulle et al. 2010; Muthukaruppan and Paramasamy 2010) or in the field (Martin 1986; Reddy and Reddy 1992). Evaluation was achieved using different indicators that were investigated at various organisation levels. Indeed, changes in responses to the presence of a chemical compound such as a pesticide can be measured at (1) the infra-individual level, e.g. gene expression, enzyme activities, (2) the individual level, e.g. survival, fecundity and behaviour and (3) the community level, e.g. diversity and community structure. Usually, the objective of studies that are made at infra-individual and individual levels is to extrapolate the risks or effects to higher organisation levels, mainly the population level. Some responses are the direct result of a toxic effect. For instance, a contaminant may affect the expression of a gene (infra-individual level) involved in a physiological function (higher level). This has been highlighted using metal pollution for the gene expression of annetocin which is a hormone involved in reproduction of the earthworm $E$. fetida (Ricketts et al. 2004). Other responses, probably most, are indirect responses of compensation or restoration, e.g. physiological plasticity or homeostasis (Ankley et al. 2006). Indeed, animals that allocate resources to the detoxification of contaminants are likely to allocate less resource to other functions such as reproduction or growth. To provide a heuristic and comprehensive perspective of pesticide effects on earthworms, we have to consider consequences of pesticides at all these organisation levels. This might include analysing how the effects at lower levels cascade onto higher levels and even allow the early prediction of consequences at higher levels. In this review, we want to emphasise the importance of documenting pesticide effects at all organisation levels and all earthworm species that may be affected.

The aims of this review are (1) to list and assess the relevance of the different indicators used to study earthworm responses to pesticides at different organisation levels from the infra-individual to the community level (see above), (2) to assess the effects of pesticides on earthworms at these organisation levels using substances authorised in Europe and (3) to highlight the knowledge gaps. This review brings together ecotoxicologists, soil ecologists and agronomists and presents, in an accessible way, the state of knowledge on earthworms for the ecotoxicological monitoring of pesticides. It is based on the international literature but considers only earthworms species found in Europe, i.e. excluding tropical species, as well as only plant protection 
products authorised in Europe, i.e. excluding natural compounds and metals.

\section{Effects of pesticides at different organisation levels}

\subsection{Response at infra-individual level}

\subsubsection{Literature review}

The literature review was carried out on the basis of keywords in Scopus using combinations of the following keywords: 'pesticide* earthworm* biomarker* indicator* herbicide* fungicide* insecticide* genotoxic* biochemical* cellular*' in Topics. We retrieved several hundred publications. Those which appeared relevant for the review were sorted using the titles, the abstracts and the full texts. To complete the review, starting from the selected references, authors that had produced references on the subject of interest were identified and all their publications were studied. This procedure allowed us to select a corpus of about 76 references.

\subsubsection{Indicators at infra-individual level}

One approach to meet the social demand for biomonitoring methods is the development of indicators at infra-individual level. Biomarkers describe effects induced by various environmental stresses at any level of biological organisation, from the cell to the ecosystem. However, the term biomarker is more commonly used in a more restrictive sense, namely infra-individual changes resulting from individual exposure to xenobiotics (Lagadic et al. 1994). This is the definition we used here. This approach considers that the most appropriate method to detect the biological effects of contaminant exposure is to investigate the effects of contaminants on biological systems. Indeed, compared with methods focusing on physical and chemical properties of soils, biomarkers are assumed to focus on the effects of the bioavailable fraction of chemicals and to integrate the putative interactive effects of complex mixtures of chemicals in the ERA. Theoretically, a biomarker can be defined from any observable and/or measurable functional response to exposure to one or several contaminants that can be characterised at the sub-individual level of biological organisation (molecular, biochemical, cellular and physiological) (Weeks 1995). Importantly, the response is assumed to indicate a departure from healthy status that cannot be detected from an intact organism (Ricketts et al. 2004; van Gestel and van Brummelen 1996; Weeks 1995). The concept of biomarker is thus based on the causal relationship between the contamination of environments by any chemical inducing a stress (e.g. pesticides, polycyclic aromatic hydrocarbons, metals) and biological changes induced by the contaminated environment. Such an approach has of course been used to investigate the ecotoxicological effects of pesticides. Paradoxically, despite the massive use of pesticides, relatively little work was identified if we restrict it to pesticides currently authorised in Europe and their effects on European earthworm species. Main biomarkers at the sub-individual level that have been investigated so far for pesticides are DNA damage, lysosomal damage and changes in enzyme activities (Table 1).

\subsubsection{Effect of pesticides at infra-individual level}

The bibliographic review (Table 1) shows that: (1) pesticides can cause DNA damage in earthworms; two methods can be used to demonstrate DNA damage: the micronucleus test and Comet assay, the latter being much more sensitive than the former (Casabé et al. 2007; Klobučar et al. 2011), (2) pesticides disrupt the activity level of enzymes involved in oxidative stress such as superoxide dismutase, catalase and glutathione-S-transferase (Booth and O'Halloran 2001; Schreck et al. 2008, 2012; Wang et al. 2012), (3) pesticides, in particular organophosphate insecticides, affect the activity of carboxylesterases (Sanchez-Hernandez and Wheelock 2009) and the activity of cholinesterase (Booth and O'Hollaran 2001; Collange et al. 2010; Denoyelle et al. 2007; Gambi et al. 2007; Hackenberger et al. 2008; Jordaan et al. 2012; Olvera-Velona et al. 2008; Rault et al. 2007; Schreck et al. 2008; Venkateswara et al. 2003),(4) earthworm lysosomal membrane stability, measured using the neutral red retention test, can be altered by pesticides (Booth et al. 2001a, b; Casabé et al. 2007; Gambi and al. 2007; Klobučar et al. 2011; Svendsen et al. 2004) and (5) sub-cellular morphology and histological alterations may be observed following exposure to pesticides (Dittbrenner et al. 2011; Venkateswara et al. 2003).

Experimental protocols of ecotoxicological studies characterising the biological response of earthworms to pesticide exposure are generally similar. Naïve individuals (see below) are exposed under control laboratory conditions, typically in microcosms (Fründ et al. 2010), to one or several levels of contaminant concentrations, using either artificially contaminated substrates or field-sampled soils. Indeed, in most studies, authors compared phenotypes of conspecific individuals differentially exposed to one or several pesticides. The use of 'naïve' organisms means that they belong to model species and/or test individuals that have never been previously exposed to contaminant and are not descended from exposed individuals. In such cases, it seems reasonable to assume that phenotypic responses observed in contaminated conditions in contrast to control conditions may not be explained by genetic differences among individuals, but rather are environmentally induced responses (i.e. 


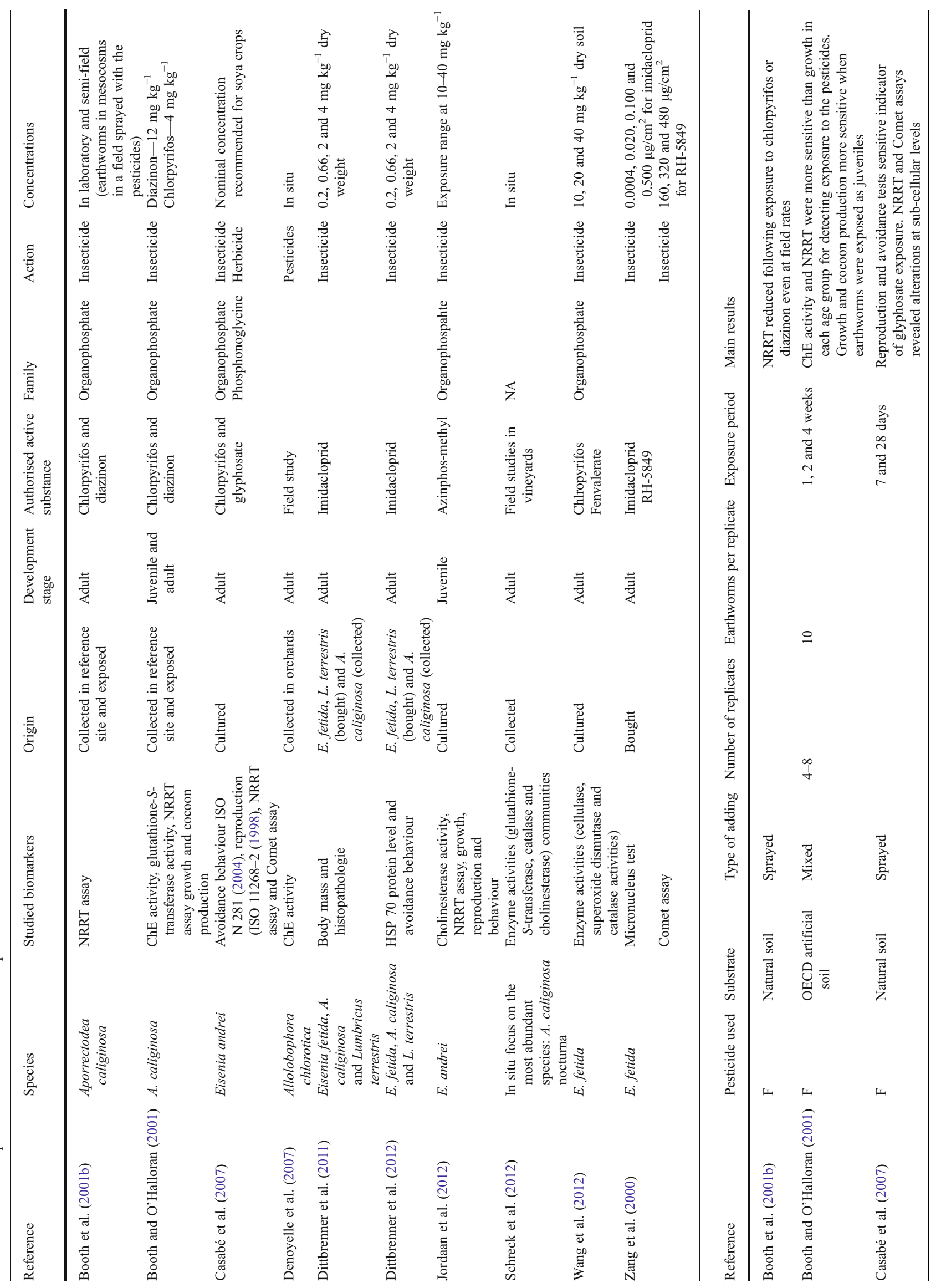




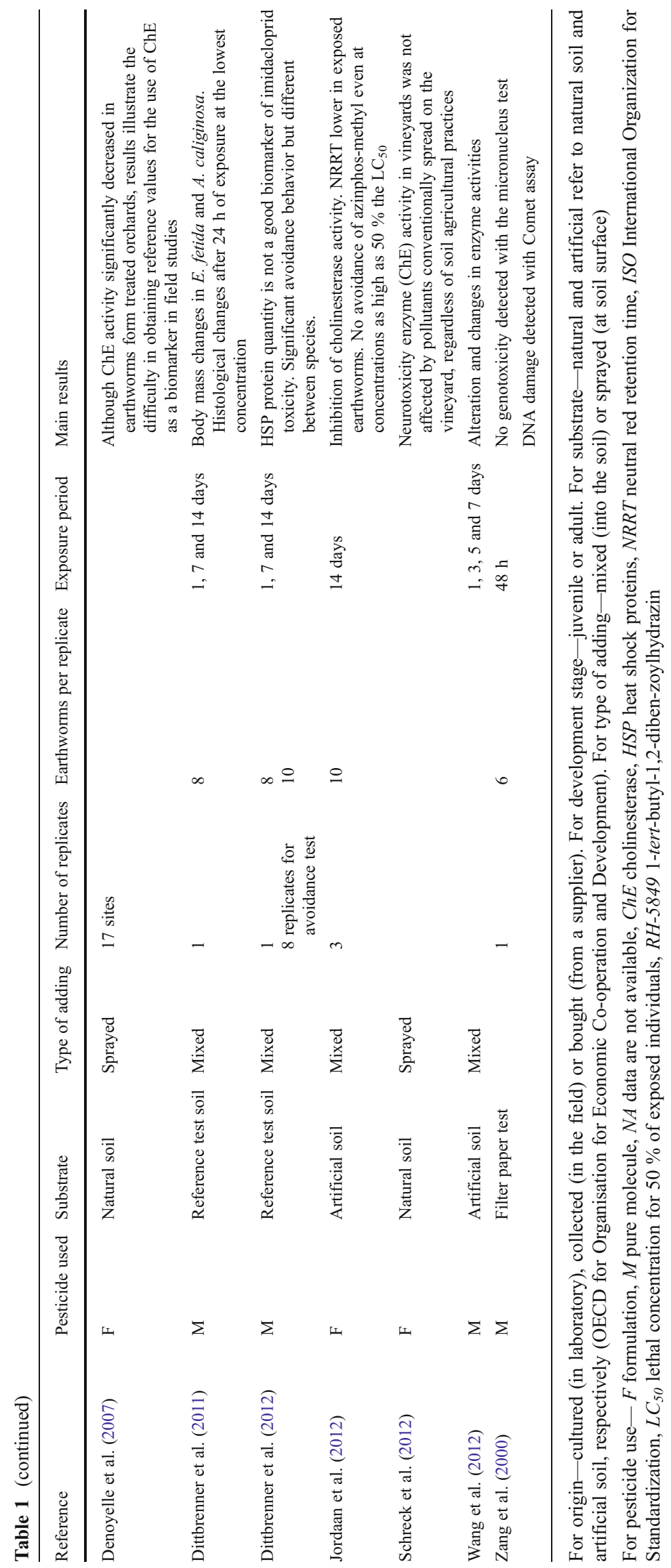


the source of phenotypic variation is mainly environmental) (Pauwels et al. 2013). Moreover, those studies are mostly based on the analysis of stress responses over a short period of time, at most equal to an individual's lifetime. Consequently, biomarkers must be considered as early markers of exposure that do not reveal long-term effects of the contaminant on the ecosystem.

It is sometimes possible to identify typical response patterns shared by different species. For example, a decrease in the neutral red retention time by lysosomes or a decrease in cholinesterase activity is frequent following exposure to organophosphate insecticide. However, it is usually difficult to identify general patterns because data for each pesticide have been recorded in one or two species only and data for each species have been recorded for only a few active substances. For example, using the Comet assay, it has been shown that some insecticides (like chlorpyrifos) used at the commercially recommended rates cause DNA damage in Eisenia sp. (Casabé et al. 2007) but it is not known whether this is the case for all insecticides. It is therefore not clear whether all oligochaete annelids have the same sensitivity to insecticides (probably not) and/or if all insecticides cause similar DNA damage (probably not).

In soil ecotoxicology, model species are usually chosen from species that are easy to maintain and breed in laboratory conditions and for which molecular tools are available. They do not necessarily occur naturally on polluted soils. Considering soil ecotoxicology in oligochaete annelids, model species are mostly from the genus Eisenia. E. fetida and Eisenia andrei, in particular, have been used in most toxicological studies (Sanchez-Hernandez 2006), although species from the Lumbricus genus are increasingly studied (Morgan et al. 2007). In particular, E. fetida is the reference earthworm in international toxicity tests (Nahmani et al. 2007a, b). In recent years, ecotoxicological investigations have benefited greatly from the emergence of molecular biology techniques, which lead to a better understanding of the mechanisms of contaminant action at molecular level (see Brulle et al. 2010). Paradoxically, although these approaches have been widely used to better understand the effects of metals, there is almost no molecular study focusing on the effect of authorised pesticides on earthworms. An interesting study was published in 2008 by Svendsen et al. but the pesticide was atrazine which is now banned.

Biomarker responses can also be measured in field-sampled organisms (Aamodt et al. 2007; Booth et al. 2000a; Denoyelle et al. 2007). Several studies deal with field-collected earthworms: this was to validate cholinesterase $(\mathrm{ChE})$ activity as a biomarker of pesticide exposure. Rault et al. (2007) characterised the tissue distribution (whole body, nervous tissue and crop/gizzard), activity of ChE over two seasons in six different species of earthworm collected in an unpolluted field: Lumbricus terrestris, Lumbricus castaneus, Aporrectodea nocturna, Aporrectodea caliginosa, Allolobophora chlorotica and Aporrectodea rosea. They demonstrated that $\mathrm{ChE}$ has a consistent activity in any given species and varies little between species of the same genus, suggesting that $\mathrm{ChE}$ would be a good biomarker of organophosphate insecticide. Therefore, when earthworms belong to natural populations that have been exposed to contaminants over a long period of time, their response might be different since they may have evolved to limit the harm caused by contaminants (Pauwels et al. 2013).

Thus, the measurement of infra-individual parameters has been primarily developed using model species and naïve earthworms in short-term laboratory experiments. A direct transfer of these results to natural populations that have been exposed to pesticides for generations can be envisaged, but only if caution is used.

\subsection{Response at individual and population levels}

\subsubsection{Literature review}

The literature review was carried out on the basis of keywords in ISI Web of Knowledge, using the 'All Databases' option, with the following formula: 'earthworm* and (pesticide* or herbicide* or fungicide* or molluscide* or nematicide* or insecticide*)' in Topics. We retrieved more than 1,700 publications. Those which appeared relevant for the review were sorted using the titles, the abstracts and the full texts. To complete the review, starting from the previously selected references, authors that had produced papers on the subject of interest were identified and their publications were studied. This allowed us to select a corpus of about 150 relevant references.

\subsubsection{Indicators and effects at individual and population levels}

Life history traits In the studies made before the 1980s, generally only mortality was assessed, using $\mathrm{LC}_{50}$, i.e. lethal concentration for $50 \%$ of exposed individuals. However, as pointed out by Neuhauser et al. (1985), 'reproduction may be inhibited or halted at chemical concentrations far below a given $\mathrm{LC}_{50}$ '. In aquatic ecotoxicology, it has been proven that the $\mathrm{LC}_{50}$ and the no observed effect concentration (NOEC) for reproduction and growth are generally similar, while in terrestrial ecotoxicology, the NOEC is often much lower than the $\mathrm{LC}_{50}$ (van Gestel et al. 1992). Vermeulen et al. (2001) explain that '[...] Mortality as a measure of a population's sensitivity to a chemical is regarded as neither a sensitive nor a relevant ecological parameter'. Even if molecules do not significantly affect earthworm survival, they may affect other life history traits and behaviour, resulting in the reduction of populations and/or of earthworm activity, 
which may influence soil functioning (Lal et al. 2001; Luo et al. 1999; Slimak 1997). The explanation is that stress caused by the presence of a contaminant may divert energy from growth, reproduction and/or burrowing activity. Instead, energy is used to ensure the survival of the organism (Gibbs et al. 1996; Odum 1982). Many authors therefore stress the importance of studying effects of pesticides on reproduction or growth in addition to survival (Choo and Baker 1998; Yasmin and D'Souza 2010). Addison and Holmes (1995), Kokta (1992a) and Neuhauser and Callahan (1990) have suggested that cocoon production (Fig. 3) is a more sensitive indicator of pesticide-induced stress than growth in earthworms.

Using available databases that provide information on almost 400 pesticides (ANSES Agritox 2012; PPDB 2013), we found that less than $5 \%$ of pesticides have a $\mathrm{LC}_{50}$ below or equal to $10 \mathrm{mg} \mathrm{kg}{ }^{-1}$, which is considered as moderately to highly toxic for the species $E$. fetida (PPDB 2013), i.e. one acaricide, two fungicides, four herbicides and nine insecticides. We found information on reproduction for only 97 pesticides. For more than $50 \%$ of them, we found a NOEC $<10 \mathrm{mg} \mathrm{kg}^{-1}$, i.e. 12 insecticides, 23 fungicides, 12 herbicides, 3 nematicides and 2 molluscicides. According to these databases, insecticides and fungicides appear to be the most toxic chemicals affecting survival and reproduction respectively. Herbicides are well represented in toxic chemicals despite what some authors have said (Lee 1985). The pyrimidine insecticides seem nontoxic to earthworms and triazine herbicides appear to have a moderate effect on earthworm populations (Edwards and Bohlen 1996). The most harmful pesticide families to earthworms seem to be nicotinoides, strobilurins, sulfonylureas, triazols, carbamates and organophosphates.
Despite these data, information is lacking on the pesticide effects on earthworm reproduction and growth. Studies found in the literature focus mainly on the following substances: cypermethrin, glyphosate, mancozeb, chlorpyrifos, carbendazim and dimethoate, i.e. three insecticides, two fungicides and one herbicide (Table 2). For clarity, only publications that addressed at least reproduction and/or growth parameters, i.e. not only mortality, are listed in Table 2. Moreover, studies can be performed using different substrates, e.g. soil, water and filter paper, which may change the response of earthworms to pesticide. Only tests that were done in soil are shown in Table 2.

For a given duration of exposure, when pesticides were used at agronomic rates, only few authors found significant effects on earthworm survival (Correia and Moreira 2010; Roark and Dale 1979). In general, pesticides used at these rates did not show any effect at the individual level (Addison 1996; Bauer and Römbke 1997; Capowiez et al. 2005; Choo and Baker 1998; Vermeulen et al. 2001), or they only affected earthworm growth and reproduction (Choo and Baker 1998; Correia and Moreira 2010). For instance, the use of chlorpyrifos at agronomic rates may cause a delay in juvenile growth and a decrease in cocoon production of A. caliginosa (Alshawish et al. 2004; Booth and O'Halloran 2001; Booth et al. 2000b). Glyphosate may affect cocoon hatchability and therefore the number of juveniles as well as growth, thus modifying the time to maturation (Correia and Moreira 2010; Springett and Gray 1992; Yasmin and D'Souza 2007). However, the effects of a given compound may differ between studies and/or species. For instance, Casabé et al. (2007) did not find any effect of chlorpyrifos used at agronomic rates on the reproduction of $E$. andrei. Similarly, Burrows and Edwards (2004) showed that carbendazim used at agronomic rates had no effect on

Fig. 3 Cocoons of earthworms

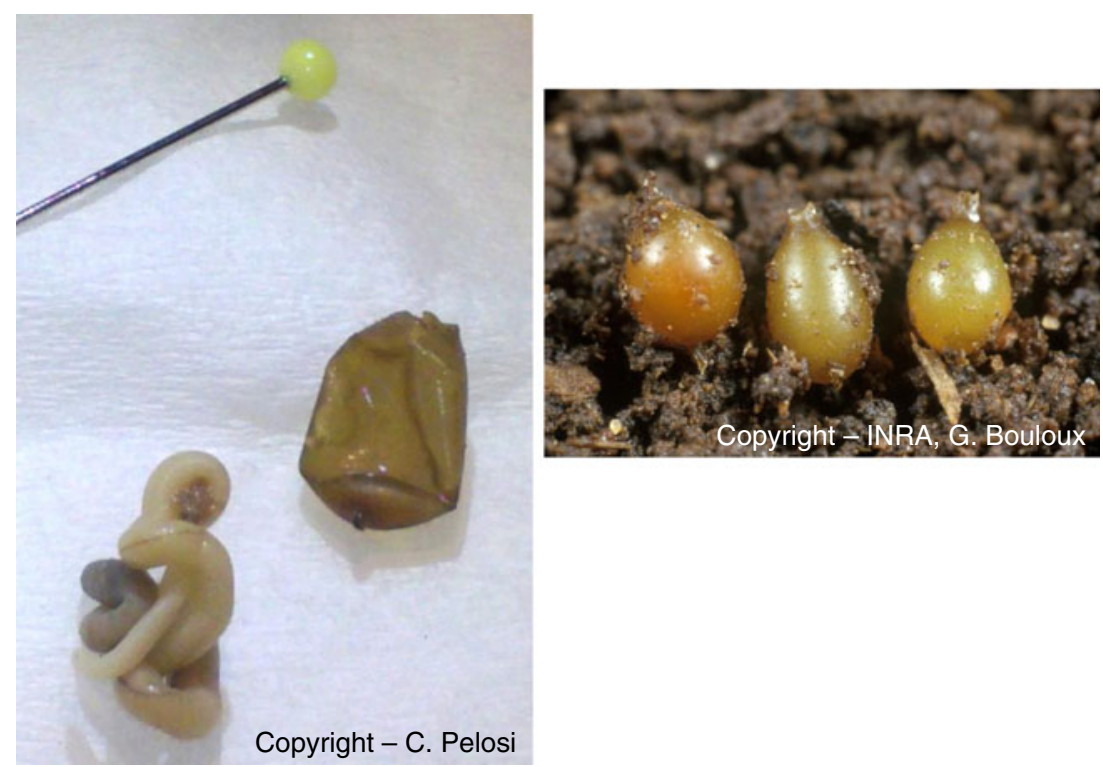




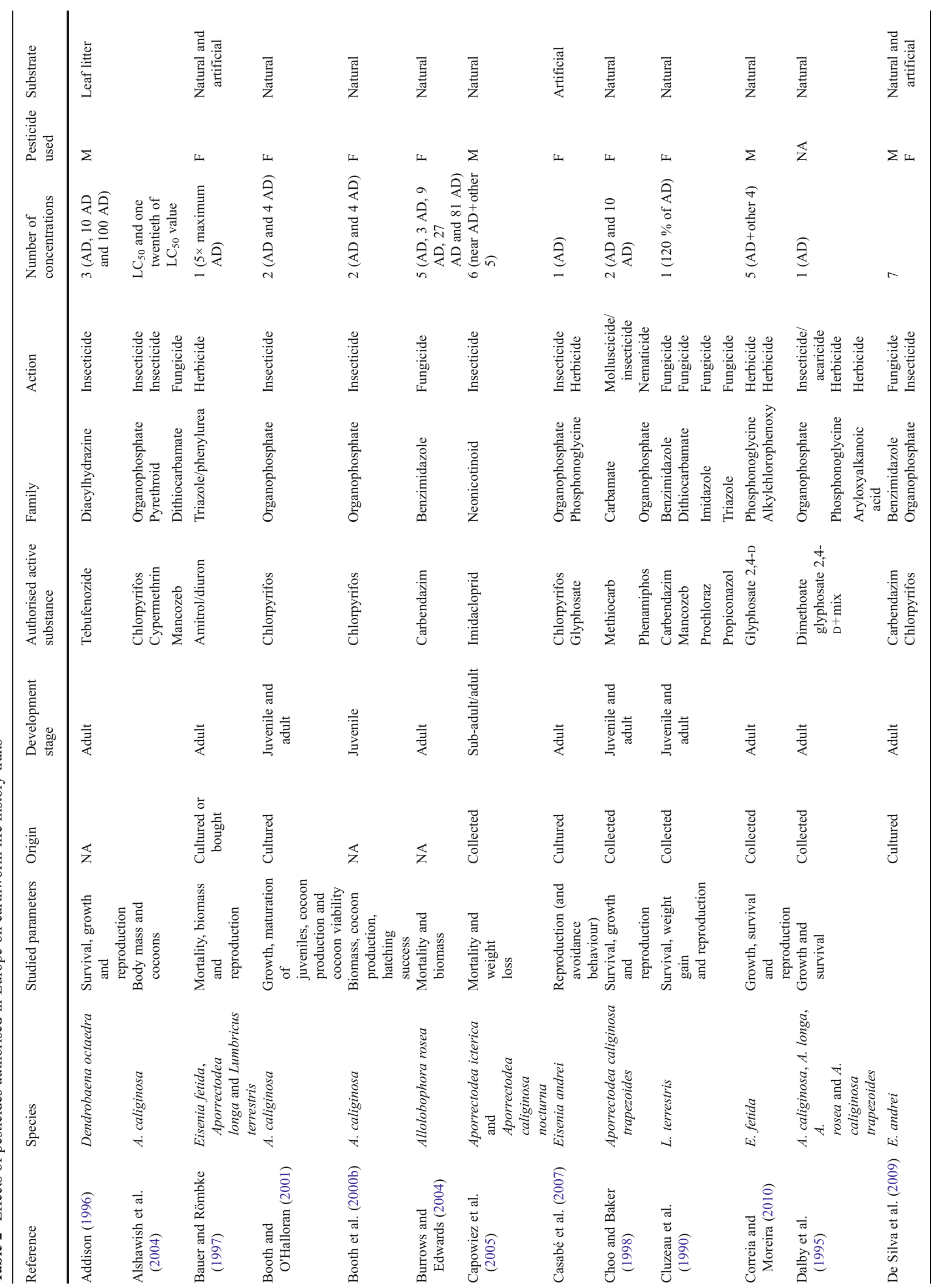




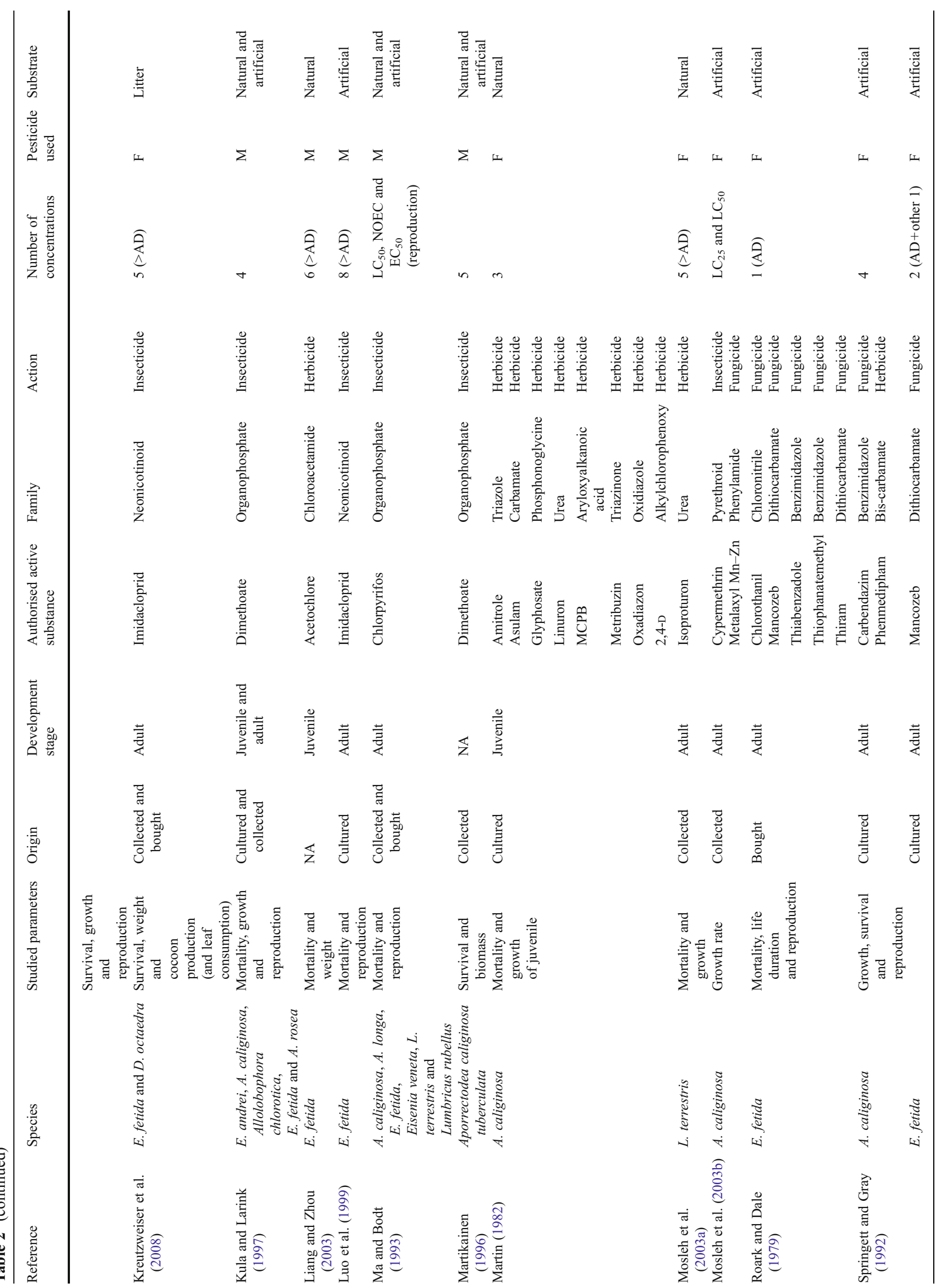




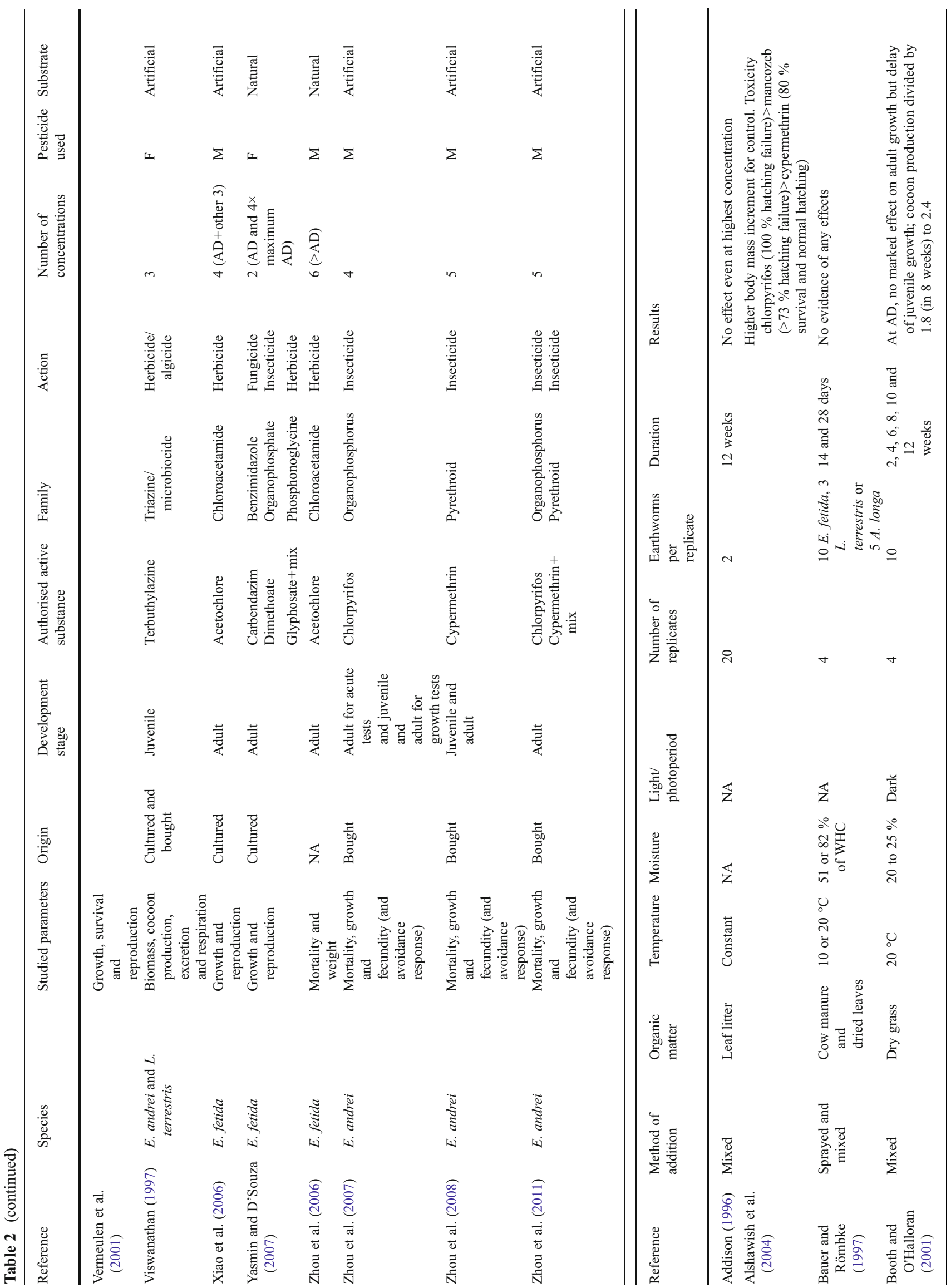




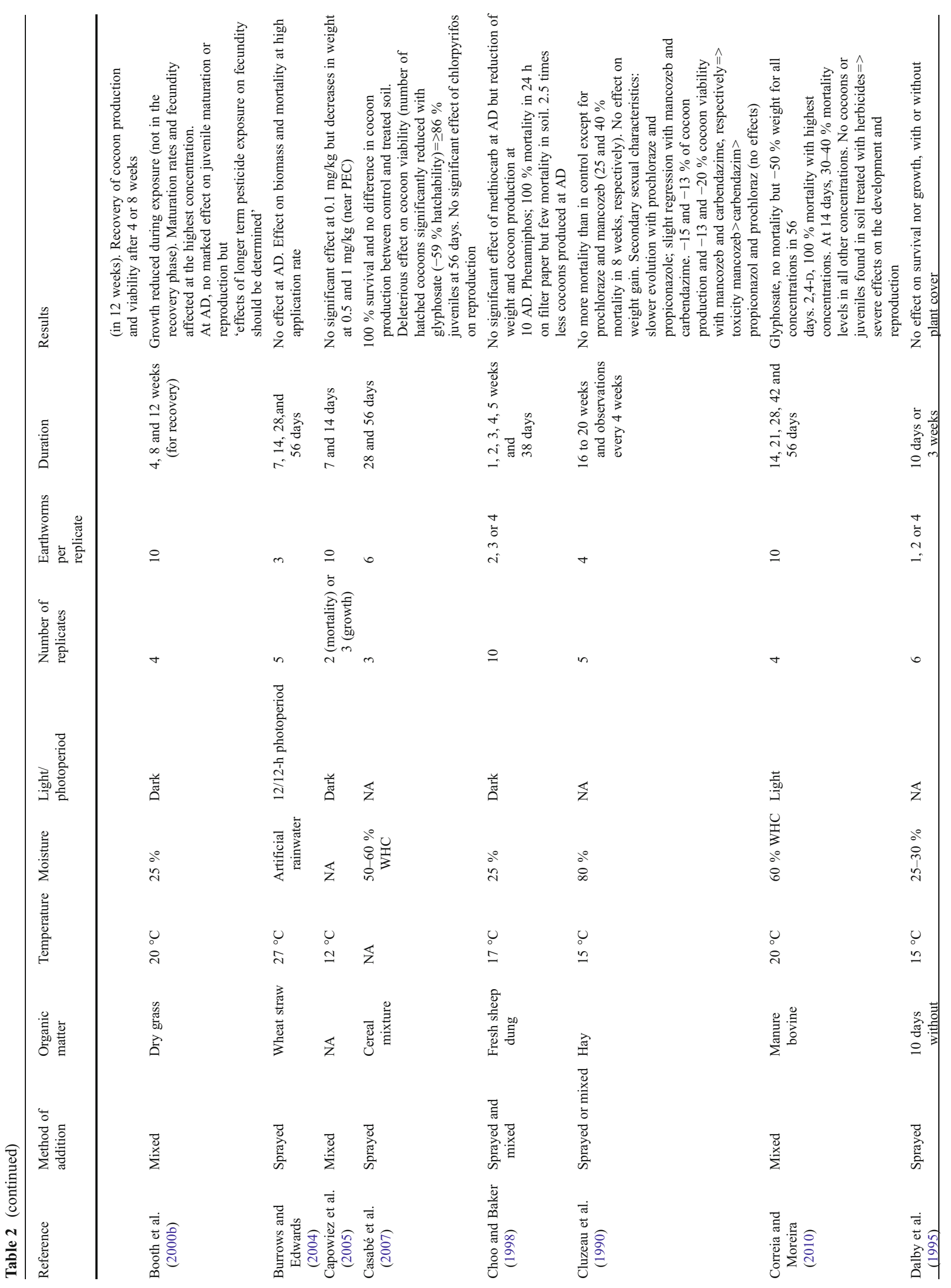




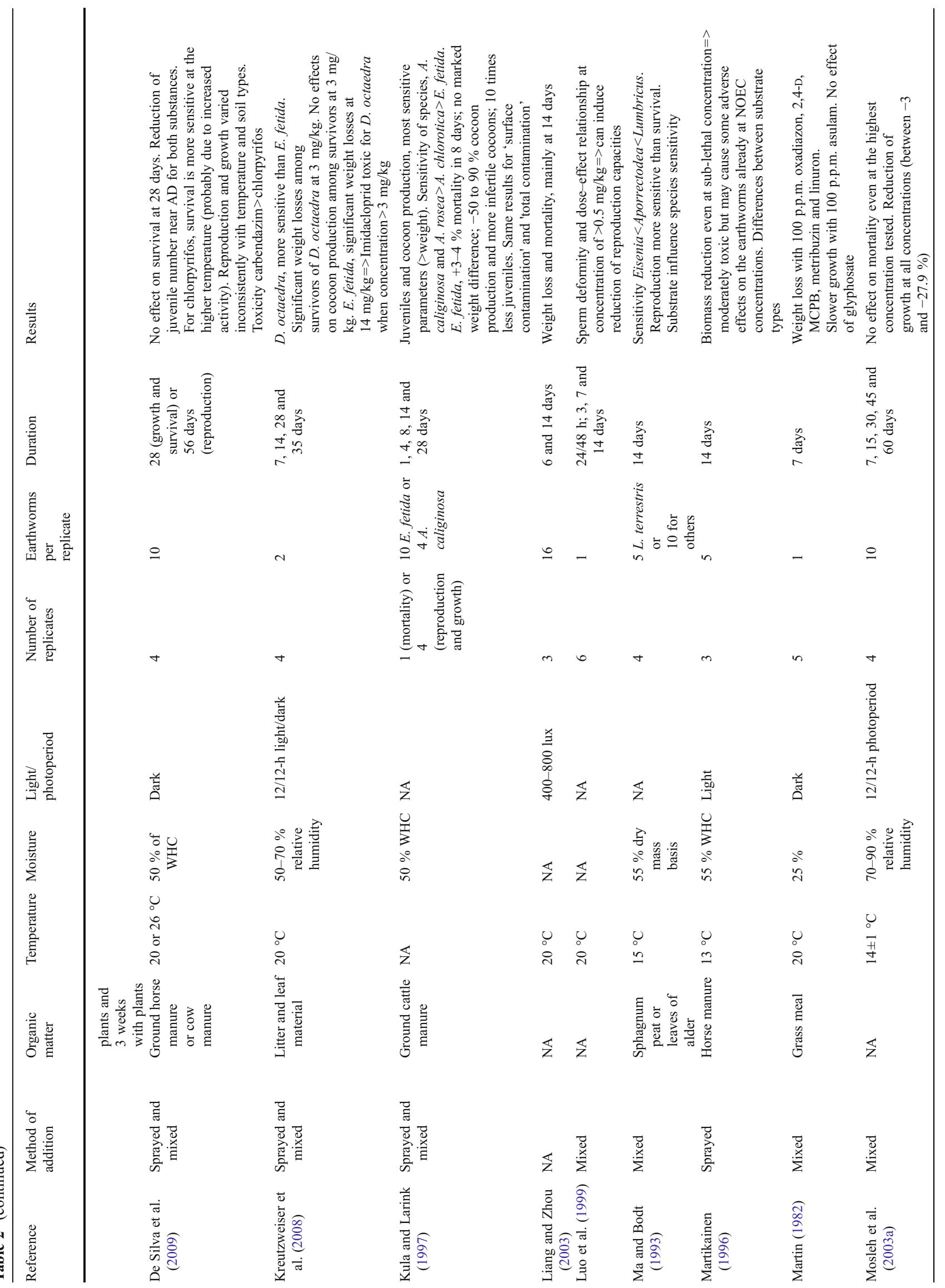




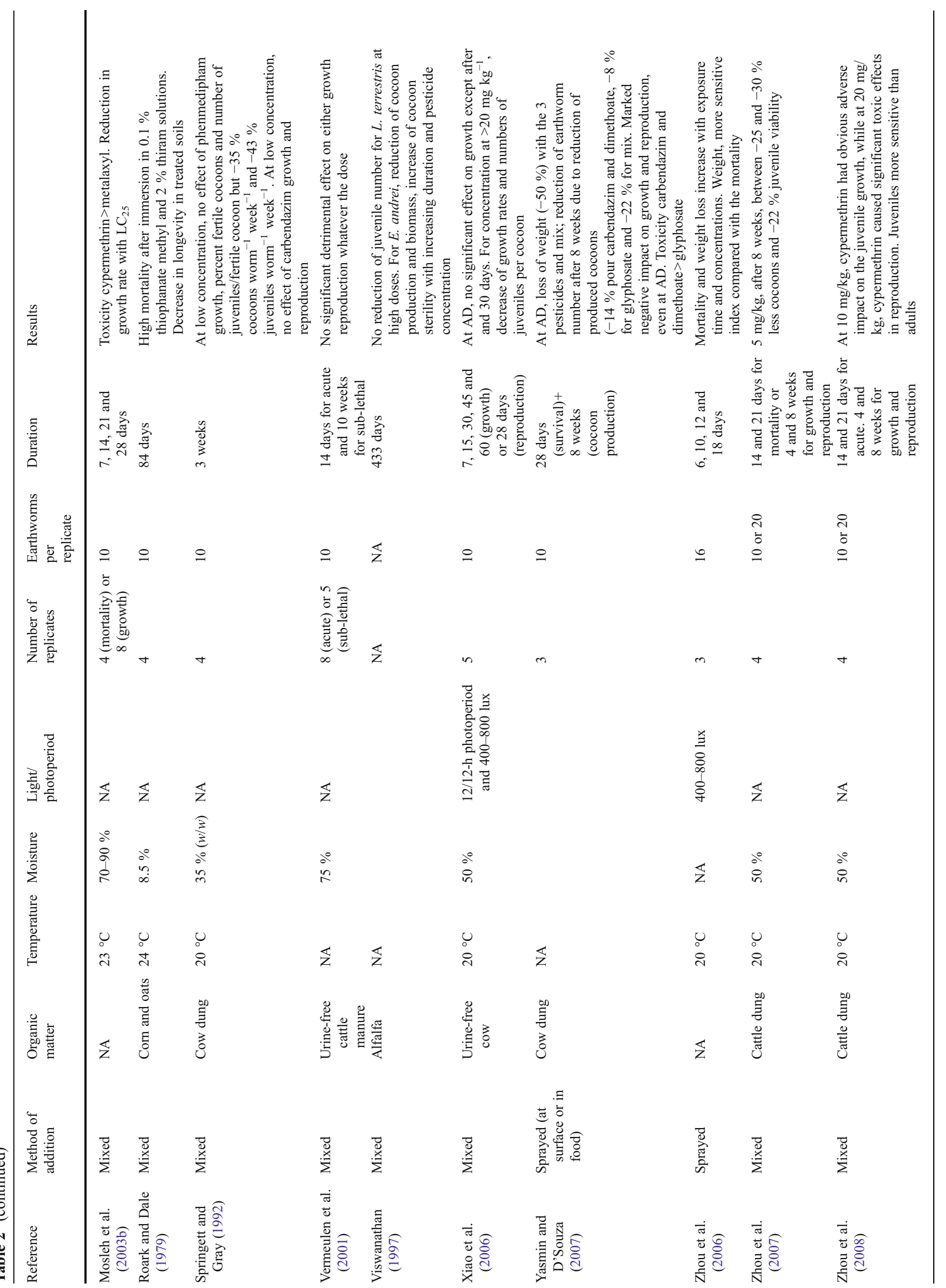


Lumbricus rubellus individuals while Yasmin and D'Souza (2007) recorded a decrease in the growth and reproduction of E. fetida. These two authors used similar concentrations of carbendazim but different commercial formulations.

According to Table 2, as soon as agronomic rates are exceeded there may be effects on mortality and almost always marked effects on reproduction and growth. If the purpose of a study is to detect an effect on earthworms, it seems that mortality is in fact the least appropriate indicator to study, followed by growth and then by reproduction (Booth and O'Halloran 2001; Kula and Larink 1997; Ma and Bodt 1993; van Gestel et al. 1992; Zhou et al. 2006).

Behaviour Markers based on behavioural patterns are generally considered to be among the most sensitive ones (Doving 1991). The advantages of behavioural markers are (1) the wide range of functions concerned, e.g. locomotion, reproduction, feeding and biological interactions, that may be linked to the individual's fitness, (2) their low specificity, i.e. they react to a wide range of pollutants and (3) their ecological relevance, i.e. effects can be related to consequences at higher biological levels. The behavioural repertoire of earthworms is rather limited compared with that of mammals, birds or insects, yet it is broad and relevant enough to address some important soil functions that are affected by their activity. Indeed, since earthworms are considered as soil ecosystem engineers, modifications of their behaviour might have important consequences for soil functioning. Four main functions were identified in the literature regarding effects of pesticide on earthworms: avoidance behaviour, burrowing behaviour, bioturbation and burial of organic matter (Table 3). The avoidance behaviour is thought to be caused by a modification of the 'habitat function' of the soil (i.e. its chemical quality). This is the basis of the normalised avoidance test (ISO 17512-1 2008). This simple test was designed to reveal significant repellence of a polluted compartment compared with a control compartment. This implies that earthworms are able to detect toxic compounds and decide to escape from them. This is the most used behavioural test for earthworms since it is very simple and cost-effective. It has been successfully used for different pesticides, mainly insecticides (Table 3 ) but in some cases a significant attraction of earthworms for polluted soils was observed (Mangala et al. 2009). Moreover, the avoidance test is less sensitive than other markers when used with neurotoxic pesticides (Perreira et al. 2010). One of the arguments against this test is that it is a repellence test rather than a toxicity test (Capowiez et al. 2003).

An obvious consequence of earthworm activity in the soil is, except for epigeics, the creation of burrows, which influences soil transfer properties. Burrowing is thus an 


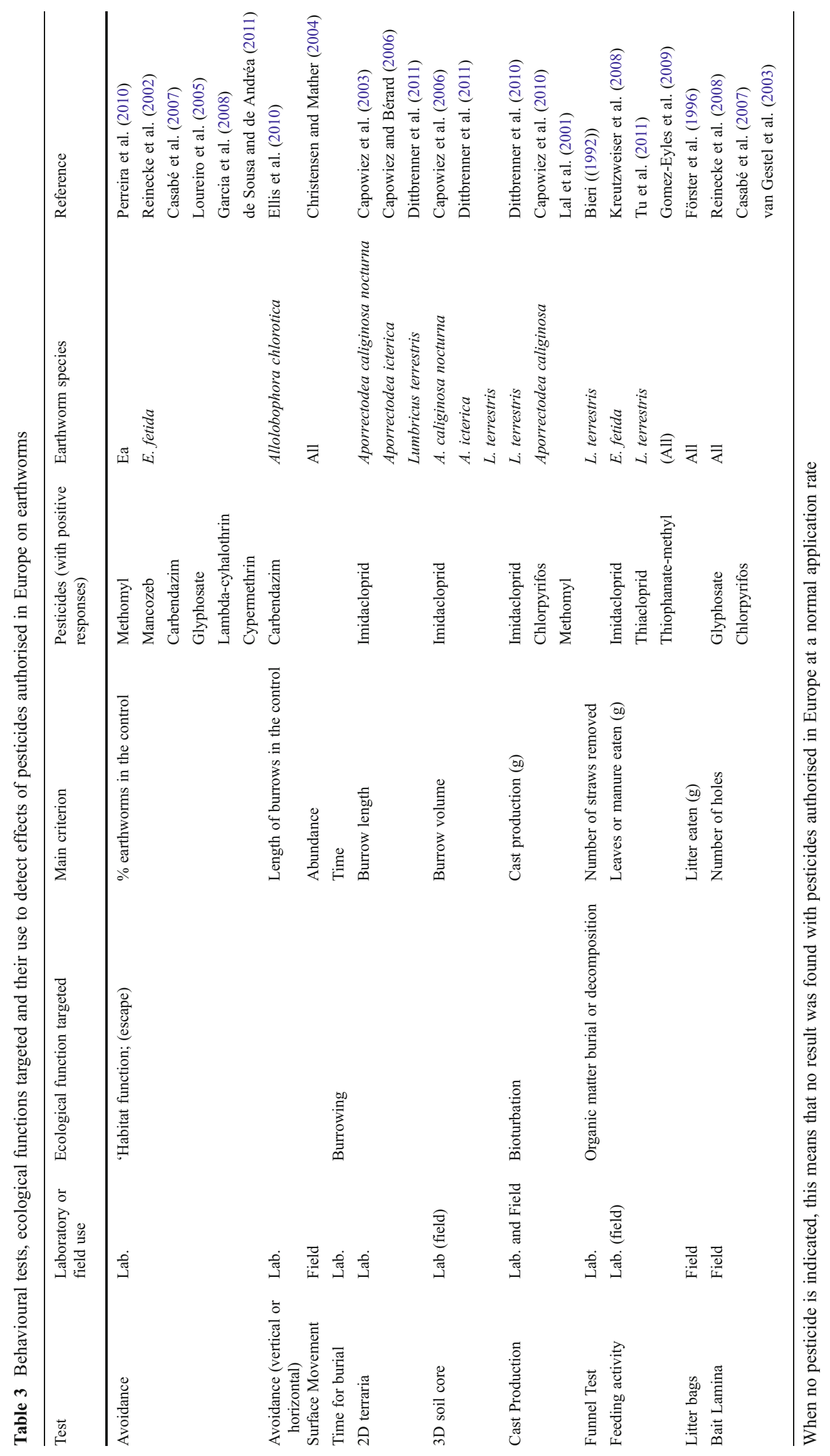


interesting measurement for ecotoxicological tests. The simplest observation that was used is the time earthworms take to burrow which is always linked to the classical experimental protocol. This is however an all or nothing kind of response. Direct observations of earthworm burrowing behaviour are difficult but studying the outcomes of this activity is possible using for instance the 2D terrarium (Evans 1947). This has been rarely used with pesticides. Capowiez et al. (2003) demonstrated that normal application rates of imidacloprid cause significant effects on the characteristics of the burrow systems, i.e. length, depth and branching rate, made by $A$. icterica and A. nocturna. However the links with soil function remained theoretical since measurements of transfer, i.e. water, gas or solutes, are not possible in $2 \mathrm{D}$. To overcome this limitation, Capowiez et al. (2006) did the same experiment in soil cores in which the burrow systems were analysed using X-ray tomography (Pierret et al. 2002) after 1 month of incubation (Fig. 4). Significant decreases in burrow length and depth were shown to be correlated with lower gas diffusion in soil, at least for A. icterica. Obviously, observations in 3D are too tedious and need technical skills and thus cannot be generalised.

Another physical consequence of earthworm activities in soil is bioturbation, i.e. the disrupting and mixing of soil by animals living in, feeding from or simply passing through it (Meysman et al. 2006). Earthworms feed on soil and burrow in the soil by ingesting soil particles. After gut transfer, the soil is egested as casts, which play an important ecological role in the soil (Lee and Foster 1991). Cast production can be used as a proxy for earthworm activity thanks to its simplicity (Capowiez et al. 2010). Cast production is estimated by sieving soil in which earthworms were incubated. So far, only three insecticides (Table 3) were shown to induce significant decreases in cast production for anecic and endogeic earthworms. Moreover, it was validated by some field observations in the case of imidacloprid toxicity (Lal et al. 2001). However, under field conditions, it is difficult to attribute decreases in cast production to a modification of individual behaviour or to effects at the population level, i.e. lethality.

The last soil function associated with earthworm behaviour that provides meaningful measurements in ecotoxicology is related to burial of litter, mainly due to anecic earthworms. Unlike in aquatic ecology, these tests are still astonishingly rarely developed in soils. One of the oldest tests is known as the funnel test (Bieri 1992). It was developed for L. terrestris, which has a well-known surface feeding behaviour. After earthworms were incubated in funnels filled with moist soil, pesticide and straws are deposited on the soil surface and the number and location of straws at the soil surface are checked daily.

Overall, measurements based on earthworm behaviour are still poorly used, with the notable exception of the avoidance test, which is the most controversial one and the least related to a soil function. There is a need for new tools that can (1) be used routinely under laboratory conditions and (2) provide an indication of important soil functions e.g. soil water transfer or organic matter decomposition, possibly under field conditions.

To summarise, studies on the effect of pesticides at the individual level generally concern earthworm life history traits and behaviour and are conducted under laboratory-controlled conditions. The existing studies cannot be used to reliably rank compounds for their toxicity because the ranking varies from one study to another. Progress could be made with tests based on earthworm behaviour.
Fig. 4 Effect of different concentrations of imidacloprid on the digging behaviour of two earthworm species (adapted from Capowiez et al. 2006)

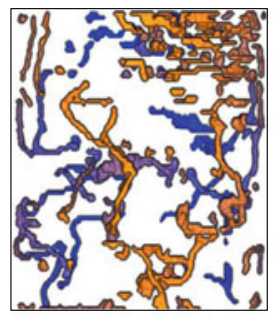

Control

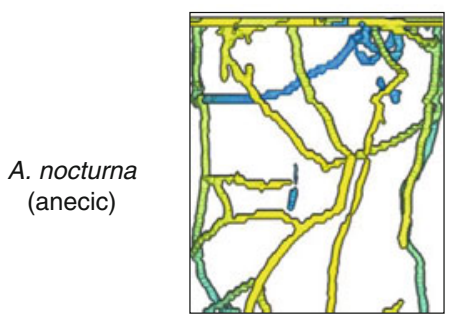

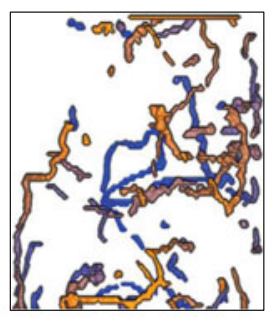

$0.5 \mathrm{mg} \mathrm{kg}^{-1}$ imidacloprid

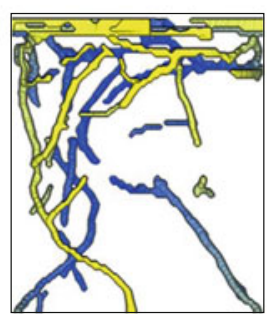

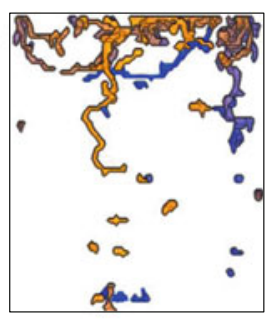

$1 \mathrm{mg} \mathrm{kg}^{-1}$ imidacloprid

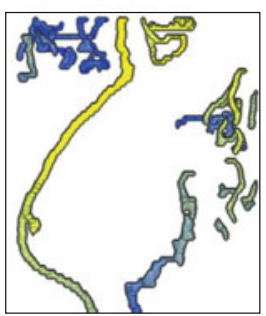




\subsection{Response at community level}

\subsubsection{Literature review, data extraction and analysis}

In order to assess the responses of earthworms to pesticides at the community level, all the combinations of the terms: earthworm*, density, biomass and community AND pesticide*, fungicide*, herbicide*, insecticide* and molluscicide* were used in the Web of Science database. To assess the effects of pesticide management on earthworms at the community level, the following combination of terms were used: earthworm*, density, biomass and community AND organic, conventional, reduced, integrated AND cropping and farming. Only studies made at field scale (Fig. 5) in European Union, and with currently authorised compounds were retained. Unpublished studies from government libraries or technical institutes were not retained.

A meta-analysis was employed to compare case studies (Hedges et al. 1999). Meta-analytical techniques allow one to determine whether individual studies share a common 'effect size' (see next paragraph), or, in other words, whether there is a single overall effect size that describes the magnitude of the experimental effects (e.g. alternative vs. conventional farming). This technique is well adapted to our objective since many confounding factors can blur the site-specific response of earthworms to pesticides. So, in addition to recording community densities and biomass in plots, site characteristics (i.e. site latitude, soil type and soil occupancy) and sampling details (i.e. sampling year, season, method and volume) were considered and included in the database. We aimed at exploring the influence of site characteristics (latitude and soil type), the sampling procedure (season and method), the type of farming practices (organic, reduced or integrated) and the type of crop. Crops were divided into five groups according to the level of available information: cereal, non-cereal, grassland, ley or unknown.

We used a response ratio defined as $\ln$ (treatment mean/control mean) where conventional and alternative pesticide use are regarded as the control and treatment, respectively (Hedges et al. 1999). This metric, termed the 'effect size', has become commonly used in meta-analysis (Mosquera et al. 2000). It is designed to measure relative differences, often appropriate in ecological studies.

Many indices are used by community ecologists to describe the three dimensions of biodiversity, i.e. structure, composition and function. However, in the context of ecotoxicology, such indices are rarely computed (Decaëns et al. 2008; Hedde et al. 2012; Pelosi et al. 2009a) and community parameters are mainly restricted to density and biomass in most studies on pesticide effects. This approach may have prevented the exploration of the whole earthworm community response.

Two questions raised in this section: (1) is it possible to distinguish a general response of earthworm communities to a restricted set of pesticides? And (2) do conventional and alternative, i.e. no or low pesticide use, cropping systems have different earthworm communities?

\subsubsection{Effect of pesticides at community level}

Regarding the first of these questions, it is not yet possible to identify a general response of an earthworm community to a set of pesticides. The effects of currently EU-authorised compounds per se on a community are rarely addressed. Amongst the few studies, we may cite Römbke et al. (2004) and Iglesias et al. (2003). Römbke et al. (2004) extracted intact soil columns from the field and exposed real earthworm communities to a fungicide, the carbendazim applied in the formulation Derosal $^{\circledR}$. Sixteen weeks after application of the chemical, decreases were observed in the abundance as well as the biomass of the earthworm community. However, the experimental design was not suitable to evaluate effects on diversity. The authors calculated $\mathrm{EC}_{50}$ values (i.e. half maximal effective concentration values) for the effect of carbendazim on earthworm abundance (2.04$48.8 \mathrm{~kg}$ active ingredient $\mathrm{ha}^{-1}$ ) and on biomass (1.02$34.6 \mathrm{~kg}$ active ingredient $\mathrm{ha}^{-1}$ ). On the other hand, in a field study, Iglesias et al. (2003) did not find any effect on earthworm density of formulated metaldehyde (Caraquim ${ }^{\circledR}$ ) at the manufacturer's recommended rate.
Fig. 5 Illustration of the earthworm sampling method combining a chemical extraction and $\mathbf{b}$ hand-sorting
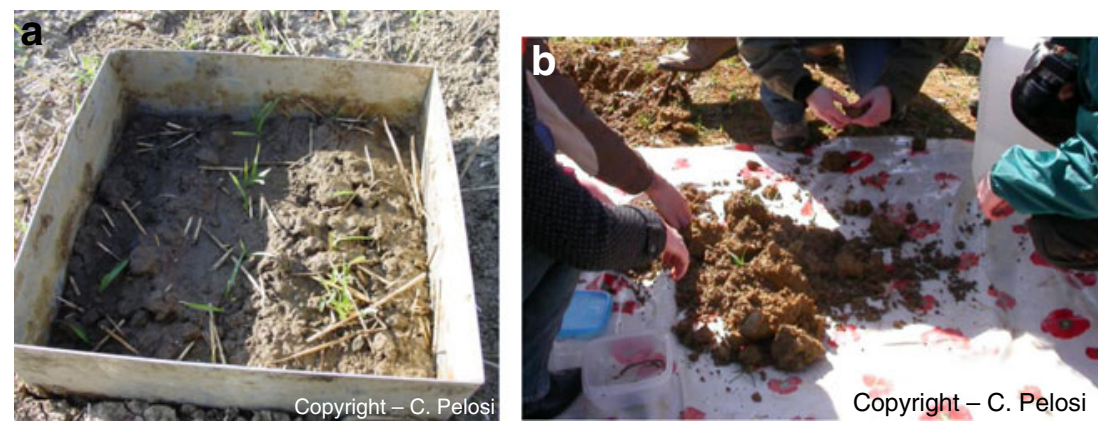
To address the second question, nine articles that met our criteria (Table 4) were studied in detail. Total earthworm density (individuals per square metre) and/or biomass (in grammes per square metre) were used as response variables. Conventional farming was compared with organic farming (six studies) or other strategies, i.e. reduced inputs, integrated or bio-dynamic farming. Studies covered an 18-year period from 1990 to 2008. In total, 68 pairs of plots reporting earthworm biomass and 82 reporting earthworm densities were collected. The mean overall effect sizes were $0.17( \pm 0.15)$ and $0.38( \pm 0.20)$ for earthworm density and biomass respectively (Fig. 6). These values differed significantly from 0 for both density $(t=2.20 ; p<0.030)$ and biomass $(t=3.63 ; p<0.001)$. This means that, on average, using little or no pesticides is beneficial for earthworm communities. The two-fold higher effect size recorded for biomass probably reveals that changes in species composition also occurred in favour of larger individuals, e.g. anecic earthworms. These species play an important role in soil behaviour since they influence key soil properties such as structural stability and fertility (Fig. 2a, b), via production of casts and porosity as well as via the enhancement of organic matter mineralisation. Changes in earthworm composition should thus play a major role in ecological intensification of agroecosystems.

To help explain these overall effect sizes, six factors that may influence the results (Lavelle and Spain 2001) were recorded from the literature, i.e. site latitude, soil type, sampling season, sampling method, type of alternative practice and crop. Unfortunately, soil type and sampling season were not included in the analyses because some studies did not report data season by season and most studies did not report data on soil characteristics in a similar way (e.g. soil type or soil texture). Latitude had no effect on the effect size of alternative practice on biomass and density. Similarly, the type of alternative practice did not affect these two effect sizes, whereas the sampling method, i.e. hand-sorting, chemical extraction and combined methods did. Chemical extraction and combined methods induced a significantly positive effect size, i.e. 0.51 and 0.41 for biomass and 0.20 and 0.19 for density, respectively. Conversely, effect sizes calculated from hand-sorting collections were less than 0.06 and did not differ from the null hypothesis. The extraction method is known to be important when describing earthworm populations (Pelosi et al. 2009b): in particular, irritant solutions are used for a better quantification of anecic earthworms. Again, this result suggests a beneficial effect of reducing the use of pesticides on the composition of earthworm communities, with more numerous anecic earthworms in alternative systems. Moreover, the efficiency of the earthworm extraction method was also found to be affected by the sampling date (Marinissen 1992) because variations in precipitation and temperature strongly influence earthworm activity and development (Edwards and Bohlen 1996; Lee 1985). Unfortunately, we cannot discuss this point due to the lack of consistency in the sampling date collections among studies.

The type of crop resulted in different effect sizes (Fig. 6). Of the five types of crop, only cereals induced a significantly positive effect size on biomass (effect size $=0.48 ; t=0.27$; $p=0.01)$ and density (effect size $=0.23 ; t=5.24 ; p<0.01$ ). Unplowed plots, i.e. leys and grassland, presented lower effect sizes than plowed plots. This may be explained by a greater effect of soil tillage than the use of pesticides on earthworm communities. Indeed, soil tillage is known to be one of the main determinants of earthworm community assembly (Chan 2001). Non-cereal crops exhibited the highest effect sizes on both biomass and density, but the scatter in the data made them non-significant. As non-cereal crops included numerous crops, e.g. oilseed rape, linseed,

Table 4 List of selected paper retained for meta-analysis on pesticide effects on earthworm communities

\begin{tabular}{|c|c|c|c|c|c|c|c|}
\hline Author & Location & Soil & Topic & $\begin{array}{l}\text { Year of } \\
\text { sampling }\end{array}$ & Season & $\begin{array}{l}\text { Sampling } \\
\text { method* }\end{array}$ & $\begin{array}{l}\text { Sampling } \\
\text { volume }\end{array}$ \\
\hline Pelosi et al. (2009b) & France & Luvisol & Organic vs. conventional & 2005 to 2007 & Fall & $\mathrm{F}+\mathrm{HS}$ & $40 \times 40 \times 20 \mathrm{~cm}$ \\
\hline Blakemore (2000) & UK & Clay-loam soils & Organic vs. conventional & $2000 / 2001$ & Fall and winter & HS & $25 \times 25 \times 20 \mathrm{~cm}$ \\
\hline Scullion et al. (2002) & UK & Several soil type & Organic vs. conventional & 1995 to 1997 & $\begin{array}{l}\text { Fall spring and } \\
\text { early summer }\end{array}$ & $\mathrm{HS}+\mathrm{F}$ & $30 \times 30 \times 30 \mathrm{~cm}$ \\
\hline Scullion et al. (2007) & UK & Various soil type & Organic vs. conventional & 1995 and 1997 & $\begin{array}{l}\text { Fall spring and } \\
\text { early summer }\end{array}$ & $\mathrm{HS}+\mathrm{F}$ & $30 \times 30 \times 30 \mathrm{~cm}$ \\
\hline Tarrant et al. (1997) & UK & & Reduced inputs vs. conventional & 1993 and 1994 & Spring and fall & $\mathrm{F}+\mathrm{HS}$ & $50 \times 50 \times \mathrm{NA} \mathrm{cm}$ \\
\hline Irmler (2010) & Germany & $\begin{array}{l}\text { Mainly eutric cambisols } \\
\text { and haplic luvisols }\end{array}$ & Organic vs. conventional & 2001 to 2008 & Spring and fall & HS & $0.1 \mathrm{~m}^{2} \times 35 \mathrm{~cm}$ \\
\hline Eltun et al. (2002) & Norway & Drained brown earths & $\begin{array}{l}\text { Organic vs. integrated vs. } \\
\text { conventional }\end{array}$ & 1994 and 1995 & Spring and fall & $?$ (HS) & $\mathrm{NA} \times \mathrm{NA} \times 25 \mathrm{~cm}$ \\
\hline Siegrist et al. (1998) & Switzerland & Chromic luvisol & $\begin{array}{l}\text { Organic vs. biodynamic vs. } \\
\text { conventional }\end{array}$ & 1992 & Fall & HS & $0.064 \mathrm{~m}^{2} \times \mathrm{NA} \mathrm{cm}$ \\
\hline Hutcheon et al. (2001) & UK & Sandy clay & Integrated vs. conventional & 1990 to 2000 & Spring and fall & $\mathrm{F}$ & $0.25 \mathrm{~m}^{2} \times \mathrm{NA} \mathrm{cm}$ \\
\hline
\end{tabular}

$H S$ hand-sorting, $F$ formalin extraction, $N A$ data are not available 


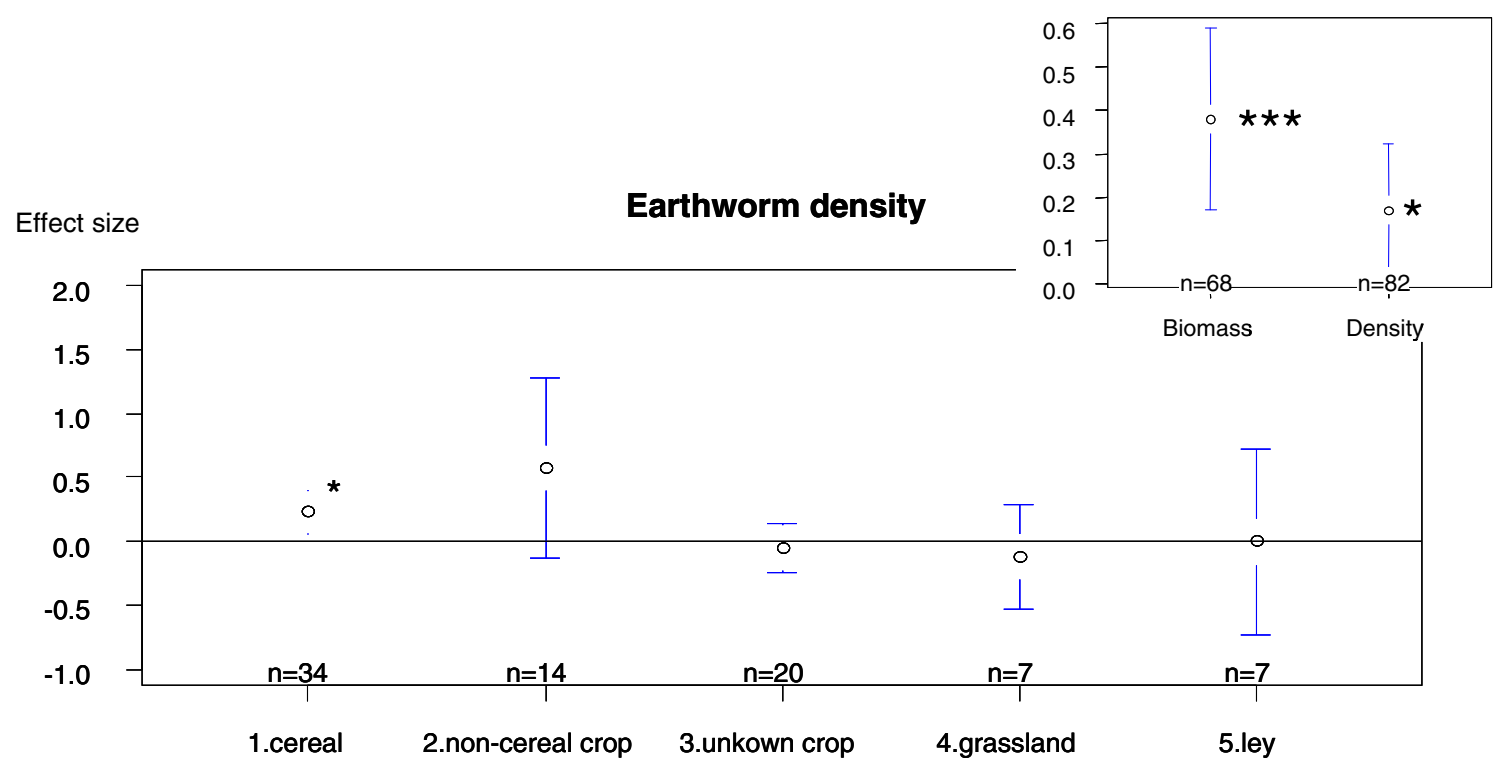

Effect size

Earthworm biomass

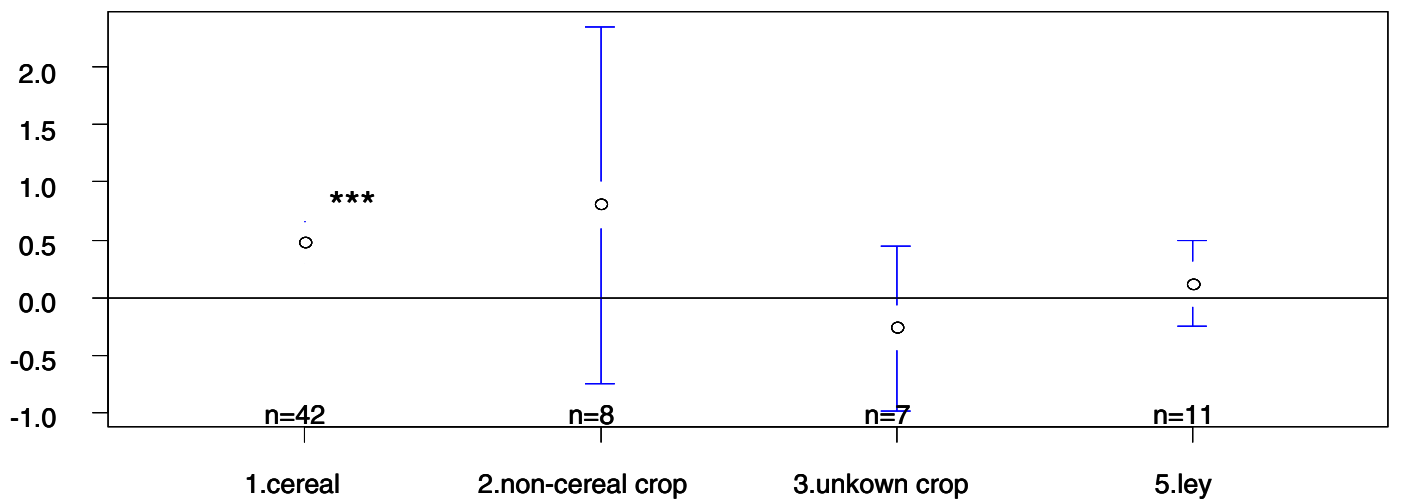

Fig. 6 Effect size of agricultural systems with low/no pesticide use compared with conventional ones on earthworm community (mean and confidence interval, $p=0.95$ ). Upper-right sub-figure corresponded to

beans and potatoes, this scatter may be due to the type of crop. More data are therefore needed to explain the effect sizes of alternative use of pesticides for each crop. Finally, this analysis shows that many sources of variation cannot be investigated in the present work. For instance, the previous crop, the soil tillage or the plot microclimate probably influence earthworm community dynamics and their response to alternative systems.

\subsection{Synthesis}

While there is much published literature on the effects of pesticides on earthworms at different organisation levels, it remains in our opinion difficult to draw general conclusions about these effects. Many questions are still unresolved and we have suggested some tentative answers to some of them: overall effects size on biomass and density. The two remaining subfigures represented the effect size of culture type on density and biomass. ${ }^{* * *} p<0.001 ; * * p<0.01 ;{ }^{*} p<0.05$

are there differences in the sensitivity to pesticides between the three earthworm ecological groups (epigeic, endogeic and anecic) or between species within these groups? Are some categories of pesticides/compounds more harmful than others to earthworms? Are some earthworm functions or traits, e.g. survival, growth, fecundity, mobility or feeding rate, more sensitive to pesticides? The difficulty in answering all these questions comes from at least two problems. Firstly, the response of earthworms to a given pesticide might be different at different organisation levels and very little effort has been made to link the responses to these different levels. Secondly, the studies were carried out in many different experimental conditions and the response of earthworms is likely to depend on environmental conditions in the field and on controlled conditions in laboratory experiments. This last point is developed in the next section. 


\section{Sources of variability in earthworm response to pesticides}

At all organisation levels, the responses of earthworms to pesticides may vary between studies depending on the toxicity of the tested compound, but also in terms of biological material used and physico-chemical conditions and duration of exposure.

\subsection{Biological models}

Whatever the exposure conditions, effects on organisms depend on species, development stage, age and origin of individuals as well as the body part or tissue which is considered. Firstly, the different species of earthworms (Fig. 7) do not have the same sensitivity to pesticides. Ma and Bodt (1993) found A. caliginosa to be more susceptible than E. fetida to chlorpyrifos, and Lumbricus species even more sensitive. The use of E. fetida andre $i$ and $A$. caliginosa respectively in the studies of Casabé et al. (2007) and Booth and O'Halloran (2001) may explain the differing effects of chlorpyrifos on reproduction. Pesticide marketing authorisation tests are performed on the species E. fetida, often used as a biological model in ecotoxicological studies (Ma and Bodt 1993). This species is easy to breed, with short generation times (Yasmin and D'Souza 2007) but is not common in the natural environment (Lowe and Butt 2007) and is on average less sensitive to pesticides than species present in cultivated fields (Pelosi et al. 2013). Besides, a distinction between the two E. fetida sub-species, i.e. E. fetida fetida and E. fetida andrei, is rarely made, although some authors have found differences between them (Lowe and Butt 2007). As shown in Tables 1, 2 and 3, the species that are commonly used in tests are E. fetida fetida, E. fetida andrei and A. caliginosa, followed by L. terrestris. Studies are often conducted on the same set of species, so that it remains difficult to predict effect of pesticides on whole communities of earthworms, encompassing epigeic, endogeic and anecic earthworms. The ecological group to which a species belongs partly determines its living and behaviour that affect the exposure of the earthworms to contaminants (Tomlin 1992; van Gestel 1992a). Culy and Berry (1995) explain that earthworms which feed at the soil surface are more affected by insecticide granules than those feeding in deeper soil layers. As the agrochemical concentration is higher in surface layers, earthworm activity may be reduced in these layers (Keogh and Whitehead 1975). For instance, individuals of $L$. terrestris, being anecic and thus living deep in the soil, are however highly exposed to pesticides because they feed on the soil surface (Edwards and Bohlen 1996; Lee 1985). Moreover, Baveco and De Roos (1996) pointed out that $L$. terrestris was more sensitive to exposure to pesticides than $L$. rubellus. $L$ rubellus being an epigeic earthworm, thus likely to be more exposed to pesticides than L. terrestris, this answer is unexpected.

Secondly, the age and development stage of earthworms may influence their sensitivity to pesticides (Lowe and Butt 2007). Many authors have shown that juvenile earthworms are more sensitive to pesticides than adults (Booth and O'Halloran 2001; Spurgeon and Hopkin 1996; Zhou et al. 2008). Ecotoxicological risk assessment using only adult specimens may thus underestimate the effects of chemicals on populations (van Gestel and Weeks 2004). According to recommendation No. 5 of Greig-Smith (1992), when growth is of interest it is preferable to use juveniles for ecotoxicological tests. In order to assess the effects of a pesticide on earthworms, van Gestel and Weeks (2004) also recommend using juveniles because it is possible to follow their weight gain. If the aim of a study is to quantify pesticide effects on a population of earthworms, all the development stages have to be considered.

Moreover, earthworms used in ecotoxicological studies may be purchased, collected in the field, laboratory cultured or from unknown origin. Each origin presents advantages and drawbacks (Lowe and Butt 2007). For instance, laboratory cultures of earthworms permit the production of cohorts of known age and history as well as the use of juveniles but they may lead to the production of individuals adapted to laboratory conditions (artificial selection) or which are inbreeding or unhealthy. According to Lowe and Butt (2007), species selection has often been based on commercial availability or on field-collected earthworms and it is difficult to determine whether the earthworms have already been exposed to a contaminant. They thus recommend using earthworms that have been bred under known laboratory conditions.

Finally, the earthworm body part used in tests varies from one study to another and infra-individual/individual studies on the whole organism or on a specific tissue may give different results (Gao et al. 2008; LaCourse et al. 2009).

\subsection{Physico-chemical conditions and duration of exposure}

Different methods are used to study the effect of pesticides on earthworms: immersion tests, injection tests, forced feeding tests, feeding on treated food or laboratory soil tests with artificial or natural soils (Edwards and Bohlen 1996; OECD 207 1984; Reinecke 1992; Robert and Dorough 1985). Contact filter paper tests (Edwards 1983; OECD 207 1984) are commonly used but only short-term effects can be measured in such tests and sub-lethal effects, such as reduced reproduction, are not addressed (Choo and Baker 1998). The contact filter paper test is used for the measurement of infra-individual and some individual parameters. Moreover, Heimbach (1984) as well as Neuhauser et al. (1986) found that contact filter paper tests provide results which are different from those obtained with soil tests. 
Fig. 7 Different earthworm species from the three ecological groups (Bouché, 1972): a epigeic, b endogeic and $\mathbf{c}$ anecic
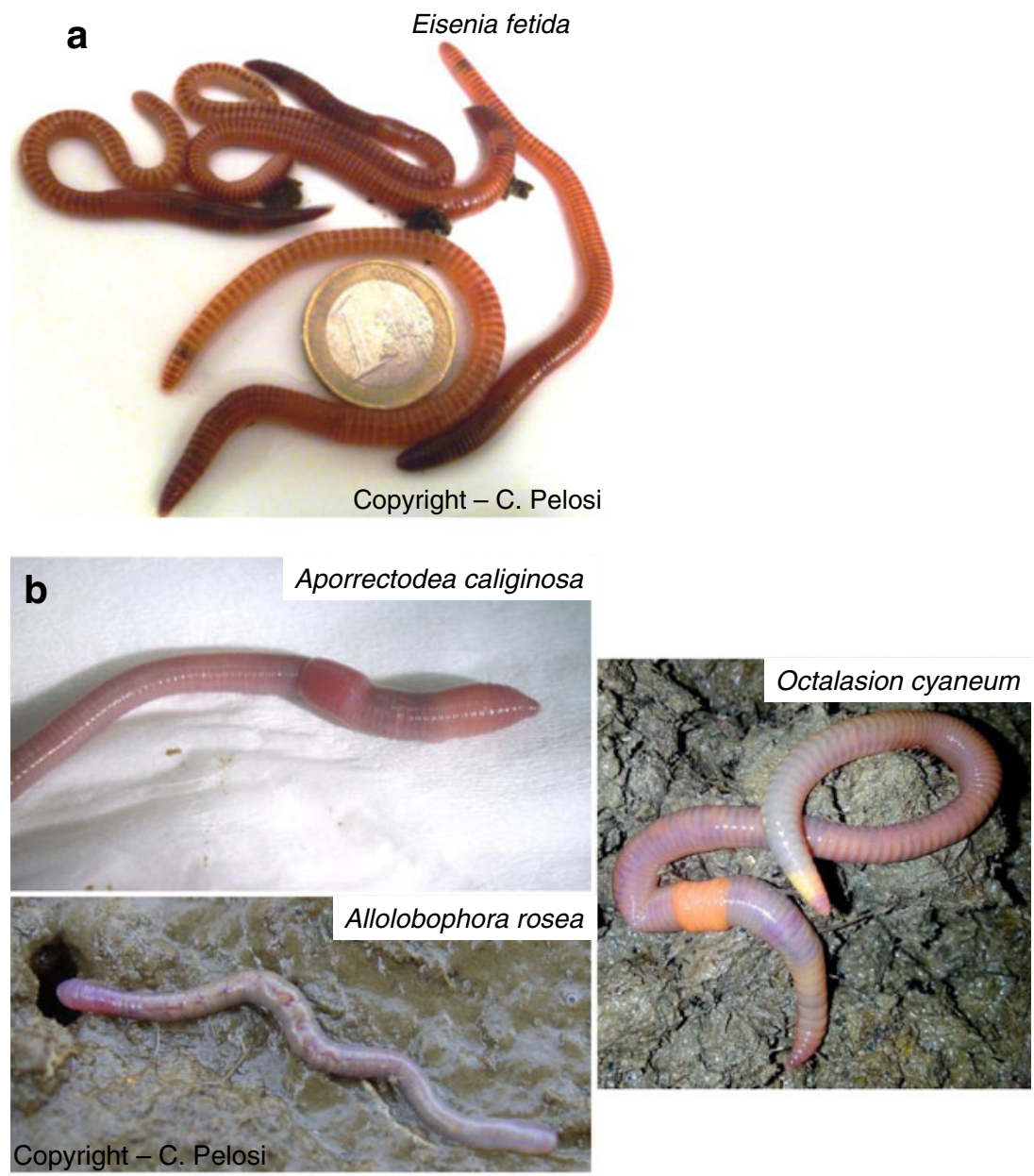

C

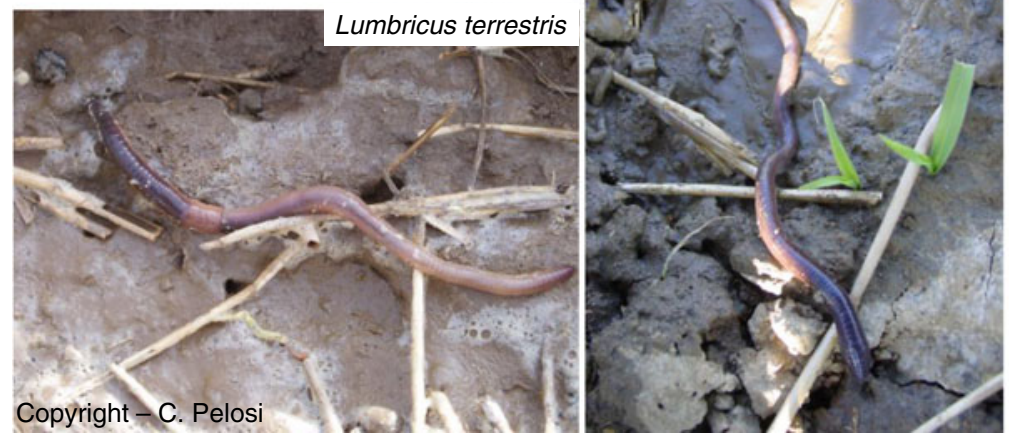

Böstrom and Lofs-Holmin (1982) explained that '[...] the number of methods used until now equals the number of papers presented on the subject'. van Gestel (1992b) suggested that organic matter influences the bioavailability and thus the toxicity of pesticides to earthworms. This author proposed to use the chemical adsorption coefficient, i.e. $K_{\mathrm{oc}}(\mathrm{OECD} 2001)$, to extrapolate results from one soil to another.

Studies on pesticide effects on earthworms can be, as already mentioned in this study, performed under laboratory or field conditions. Whatever the environment of the study, bioavailability of chemicals in soils is highly dependent on soil properties (van Gestel and Weeks 2004). For instance, toxicity in soil is influenced by both $\mathrm{pH}$ and organic matter content (van Gestel and van Dis 1988). In the same way, Högger and Ammon (1994) observed a 50 \% decrease in earthworm activity when pesticide was incorporated into soil and $90 \%$ when it was placed on the soil surface. Consequently, environmental parameters may influence the sensitivity of earthworms to pesticides. Under field 
conditions, sampling method and weather conditions influence earthworm exposure as well as sampling efficiency (Högger and Ammon 1994; Roberts and Dorough 1985). Under laboratory conditions, density of earthworms, substrate type, e.g. artificial soils like Organisation for Economic Co-operation and Development or natural soils, as well as temperature, light, moisture conditions, and the methodology used to add the pesticide and duration of the exposure are not always specified, or sometimes inappropriate, often far from field conditions (Greig-Smith 1992; Lowe and Butt 2007; Reinecke 1992) and varying from one study to another (Edwards and Bohlen 1996; Lowe and Butt 2007).

Finally, the magnitude of the observed or measured earthworm response to pesticides may be influenced by the duration of exposure. At the infra-individual level, it is possible that the response occurs before or after the biomarker measurement. In this case, no response may be seen if it is simply delayed (Zhang et al. 2013). For this reason, ideal biomarkers exhibit time and dose-dependent variations (Brulle et al. 2006). Another point is that exposure durations used under laboratory conditions are not representative of field conditions, where earthworms are continually exposed. Finally, whatever the organisation level, studies have very rarely used the same exposure duration, making it difficult to compare them.

\section{Knowledge gaps}

\subsection{Representativeness}

The first identified knowledge gap is linked to the lack of representativeness of the studied combinations of earthworm species and pesticides. More studies are needed on species that are common in European cropping systems and on pesticides that are authorised nowadays. More combinations of earthworm species and pesticide should be studied to have a more comprehensive sampling and to be able to reply with more certainty to general questions such as: What are the most harmful types of pesticide for earthworms? Are endogeic earthworms more or less sensitive to pesticides than anecic?

\subsection{Difficulties in scaling up from infra-individual} to community levels

According to van Gestel and Weeks (2004), 'there should be a correlation (linkage) between a biochemical marker response and deleterious changes to the population or community. In this case, a sub-cellular biomarker may, for example, act as an early warning of effects at the population level'. Booth and O'Halloran (2001) highlight the usefulness of biomarkers in risk assessment, explaining that biomarker responses occurred at similar or lower concentrations than those causing an adverse effect on cocoon production and cocoon viability. However, few studies have attempted to link the effects on earthworms at different organisation levels and this remains an important issue for risk assessment. One of the only attempts was made by Ricketts et al. (2004) with metals on the species E. fetida. They studied the expression level of the gene coding annetocin, a neuropeptidic hormone involved in the induction of egglaying behaviour of earthworms, under high concentrations of zinc and lead. They concluded that annetocin was a promising biomarker in earthworm ecotoxicology since it is involved in earthworm reproduction.

\subsection{Difficulties in scaling up from laboratory to field}

Some authors have shown that results from laboratory tests cannot be extrapolated easily to field conditions (Lowe and Butt 2007; Svendsen and Weeks 1997) but many others asserted that results from laboratory and field are comparable (Culy and Berry 1995; Heimbach 1992; Holmstrup 2000). van Gestel (1992a) estimated that field contaminant concentrations that affect earthworm populations are in agreement with effect levels determined in laboratory studies. This controversy highlights the complementarity between laboratory tests and field studies and the need for both approaches (Svendsen et al. 2005). However, field tests are rare due to difficulties with experimental design and interpretation of results. Few sub-lethal studies with exposures similar to situations in the field have been conducted (Kokta 1992b; Venter and Reinecke 1987), and many authors advocate microcosm studies using soils similar to natural soils (Addison and Holmes 1995; Brulle et al. 2011).

The reasons for the difficulties in extrapolating the results from laboratory to field are numerous. First of all, few studies compare the effects of pure compounds with commercial formulations as applied in fields. De Silva et al. (2010) showed that the latter are more harmful than pure compounds because of the toxic effects of adjuvants on earthworms. Secondly, some authors (Booth et al. 2000b; Booth and O'Halloran 2001; Yasmin and D'Souza 2007) suggested that earthworms recover their normal growth and reproduction rates between 4 and 8 weeks after their removal from pesticide-treated soil, but in the field they would not normally be removed from soil exposed to pesticides. This continuous exposure can have consequences from generation to generation if the compounds are persistent in the soil or if there is a transmission of some deleterious effects from parents to offspring, i.e. trans-generational effects. Brunninger et al. (1994) published one of the few studies dealing with effects of pesticides on several generations of earthworms. They studied the effect of carboruran and terbuthylazine on three generations of $E$. andrei. Exposure 
of the first generation to carbofuran decreased cocoon production in all generations while terbuthylazine harms parents but benefits the F1 generation. It appears therefore that effects of pesticides on an earthworm species over several generations depend on different factors like the compound concerned and generation. Lastly, laboratory ecotoxicological tests generally do not take into account repeated applications of several pesticide cocktails, i.e. multicontaminations and chronic exposure. There is a lack of studies on the effects of repeated agronomic doses on earthworms at different organisation levels. Besides, the effects of the many breakdown products of pesticides that enter the soil are mostly ignored as well as multi-contamination effects, e.g. synergistic, antagonistic or neutral interactions (Paoletti 1999). Yasmin and D'Souza (2007) explain that 'only a few studies describing the toxicity impact of chemical mixtures on earthworms have been published thus far, all of which focus on metals'. These authors studied the effect of three pesticides, i.e. carbendazim, dimethoate and glyphosate, alone and in combination, on the growth and reproduction of E. fetida. They showed synergistic adverse effects of the mixture compared with single pesticides. Also, Zhou et al. (2006) reported that the combination of acetochlor and methamidophos resulted in synergistic toxic effects on E. fetida. Conversely, according to Springett and Gray (1992), glyphosate and captan in combination have a smaller effect than glyphosate alone. All these contradictions and knowledge gaps highlight the need for further research into long-term earthworm exposure to mixtures of commercial formulations of pesticides.

\section{Conclusions}

From this review, we conclude that there are two main challenges: (1) the first is about knowledge, i.e. determining the real effects of pesticides on cropping systems and (2) the second concerns the methodology required to obtain this knowledge and extrapolate it to new pesticides, i.e. designing robust tests based on short-term experiments and standardised laboratory conditions that are able to predict the real field effects of new pesticides. So far, these two challenges cannot be met because we lack experiments assessing the effects of the same pesticides on the same earthworm species at different organisation levels to derive the links between the responses at these different levels. We believe that responses observed at infra-individual or individual levels have an impact on higher organisation levels (populations, communities) but there is currently no strong proof. Moreover, we also lack studies based (1) on European species and pesticides still authorised in Europe, (2) on species that are really found in cropping systems (and not only epigeic species of the genus Eisenia) and (3) on realistic conditions in terms of soil, pesticide dose and experimental duration. Another limitation of most studies is that the effect of mixtures of pesticides and chronic exposure to these mixtures are insufficiently studied, while earthworm populations face such conditions in cropping systems and it has been shown that response to mixtures of contaminants is very hard to predict from responses to the isolated contaminants. Moreover, longterm exposure of earthworm populations to contaminants could trigger the evolution of strategies to resist these contaminants. This suggests that this long-term response should be studied and that the provenance of earthworms used in experiments (which is often not clear) can be very influential: if earthworms come from populations that have been exposed to the tested pesticides for some generations they may respond differently to them. A final point that we want to highlight is the complementarity between i) laboratory studies which elucidate the mechanisms involved in the earthworm response to pesticides, and ii) field studies able to assess the state of earthworm communities in real conditions.

A broader challenge is to determine the impact of agricultural practices on earthworm populations in cropping systems and to design cropping systems that are more favourable to them and the functions they provide, which are proven to be important for the sustainability of soil fertility and plant production (Lavelle et al. 2006). Here, the difficulty is that earthworm density or biomass has often been compared between contrasting cropping systems, e.g. organic vs. nonorganic, which involve many differences in cultural practices. All these practices are likely to interact in their effects on earthworms. For example, both pesticides and tillage affect earthworms so that that complete factorial experiments combining tillage and pesticides should be carried out. It is possible that a given pesticide only affects earthworms with frequent tillage because tillage incorporates the pesticide more quickly into the soil profile or because earthworms weakened by the pesticide are no longer able to avoid the effect of tillage through rapid movement or by making galleries. As far as we know, no such experiments have been done.

Acknowledgement The FIRE (Fédération Ile-de-France de Recherche en Environnement) FR3020 is acknowledged for its interdisciplinary research framework. We would like to thank Alan Scaife for thorough editorial advice in English.

Open Access This article is distributed under the terms of the Creative Commons Attribution License which permits any use, distribution, and reproduction in any medium, provided the original author(s) and the source are credited.

\section{References}

Aamodt S, Konestabo HS, Sverdrup LE, Gudbrandsen M, Reinecke SA, Reinecke AJ, Stenersen J (2007) Recovery of cholinesterase activity in the earthworm Eisenia fetida savigny following 
exposure to chlorpyrifos. Environ Toxicol Chem 26:1963-1967. doi:10.1897/07-021r.1

Addison JA (1996) Safety testing of tebufenozide, a new molt-inducing insecticide, for effects on nontarget forest soil invertebrates. Ecotox Environ Saf 33:55-61. doi:10.1006/eesa.1996.0006

Addison JA, Holmes SB (1995) Comparison of forest soil microcosm and acute toxicity studies for determining effects of fenitrothion on earthworms. Ecotox Environ Saf 30:127-133. doi:10.1006/ eesa.1995.1016

Alshawish SA, Mohamed AI, Nair GA (2004) Prolonged toxicity of sub-lethal dosages of chemical pesticides on the body mass and cocoons of Aporrectodea caliginosa (Savigny 1826) (Oligochaeta: Lumbricidae) inhabiting Benghazi, Libya. Proc Natl Acad Sci India B Biol Sci 74:123-133

Ankley GT, Daston GP, Degitz SJ, Denslow ND, Hoke RA, Kennedy SW, Miracle AL, Perkins EJ, Snape J, Tillitt DE, Tyler CR, Versteeg D (2006) Toxicogenomics in regulatory ecotoxicology. Environ Sci Technol 40:4055-4065. doi:10.1021/es0630184

ANSES Agritox (2012). http://www.dive.afssa.fr/agritox/php/ fiches.php

Anton FA, Laborda E, Laborda P, Ramos E (1993) Carbofuran acute toxicity to Eisenia foetida (Savigny) earthworms. Bull Environ Contam Toxicol 50:407-412

Bauer C, Römbke J (1997) Factors influencing the toxicity of two pesticides on three lumbricid species in laboratory tests. Soil Biol Biochem 29:705-708. doi:10.1016/S0038-0717(96)00198-8

Baveco JM, DeRoos AM (1996) Assessing the impact of pesticides on lumbricid populations: an individual-based modelling approach. J Appl Ecol 33:1451-1468. doi:10.2307/2404784

Bieri M (1992) Guidelines for the Daniel funnel test - a laboratory test to measure side effects of pesticides on the earthworm Lumbricus terrestris L. IOBC WPRS Bull XV/3, pp. 139-144

Blakemore RJ (2000) Ecology of earthworms under the 'Haughley Experiment' of organic and conventional management regimes. Biol Agricult Horticult 18:141-159. doi:10.1080/01448765.2000.9754876

Booth LH, O'Halloran K (2001) A comparison of biomarker responses in the earthworm Aporrectodea caliginosa to the organophosphorus insecticides diazinon and chlorpyrifos. Environ Toxicol Chem 20:2494-2502. doi:10.1002/etc.5620201115

Booth LH, Hodge S, O'Halloran K (2000a) Use of cholinesterase in Aporrectodea caliginosa (Oligochaeta: Lumbricidae) to detect organophosphate contaminations: Comparison of laboratory tests, mesocosms and field studies. Environ Toxicol Chem 19:417-422. doi:10.1002/etc.5620190222

Booth LH, Heppelthwaite VJ, O'Halloran K (2000b) Growth, development and fecundity of the earthworm Aporrectodea caliginosa after exposure to two organophosphates. Proceedings Conf Proc NZ Plant Prot Soc 53:221-225

Booth LH, Hodge S, O'Halloran K (2001a) Use of biomarkers in earthworms to detect use and abuse of field applications of a model organophosphate pesticide. Bull Environ Contam Toxicol 67:633-640. doi:10.1007/s001280171

Booth LH, Heppelthwaite VJ, Webster R, O'Halloran K (2001b) Lysosomal neutral red retention time as a biomarker of organophosphate exposure in the earthworm Aporrectodea caliginosa: Laboratory and semi-field experiments. Biomarkers 6:77-82. doi: $10.1080 / 135475001452823$

Böstrom U, Lofs-Holmin A (1982) Testing side effects of pesticides on soil fauna - A critical literature review, Report 12. Swedish University of Agricultural Science, Uppsala

Brulle F, Mitta G, Cocquerelle C, Vieau D, Lemière S, Lepretre A, Vandenbulcke F (2006) Cloning and real-time PCR testing of 14 potential biomarkers in Eisenia fetida following cadmium exposure. Environ Sci Technol 40:2844-2850. doi:10.1021/es052299x

Brulle F, Morgan AJ, Cocquerelle C, Vandenbulcke F (2010) Transcriptomic underpinning of toxicant-mediated physiological function alterations in three terrestrial invertebrate taxa: a review. Environ Pollut 158:2793-2808. doi:10.1016/j.envpol.2010.06.019

Brulle F, Lemiere S, Waterlot C, Douay F, Vandenbulcke F (2011) Gene expression analysis of 4 biomarker candidates in Eisenia fetida exposed to an environmental metallic trace elements gradient: a microcosm study. Sci Total Environ 409:5470-5482. doi:10.1016/j.scitotenv.2011.08.040

Brunninger B, Viswanathan R, Beese F (1994) Terbuthylazine and carbofuran effects on growth and reproduction within 3 generations of Eisenia andrei (Oligochaeta). Biol Fertil Soils 18:83-88. doi:10.1007/BF00336450

Burrows LA, Edwards CA (2004) The use of integrated soil microcosms to assess the impact of carbendazim on soil ecosystems. Ecotoxicology 13:143-161. doi:10.1023/B:ECTX.0000012411.14680.21

Càceres T, Megharaj M, Venkateswarlu K, Sethunathan N, Naidu R (2010) Fenamiphos and related organophosphorus pesticides: environmental fate and toxicology. In: Whitacre DM (ed) Reviews of environmental contamination and toxicology, vol 205. Springer, New York, pp 117-162. doi:10.1007/978-1-4419-5623-1_3

Callahan CA (1984) Earthworms as ecotoxicological assessment tools. U.S. Environmental Protection Agency, Washington, DC, EPA/ 600/D-84/272 (NTIS PB85124691)

Capowiez Y, Bérard A (2006) Assessment of the effects of imidacloprid on the behavior of two earthworm species (Aporrectodea nocturna and Allolobophora chlorotica) using 2D terraria. Ecotox Environ Saf 64:198-206. doi:10.1016/ j.ecoenv.2005.02.013

Capowiez Y, Rault M, Mazzia C, Belzunces L (2003) Earthworm behaviour as a source of biomarkers - a study case with imidacloprid. Pedobiol 47:542-547. doi:10.1078/0031-4056-00226

Capowiez Y, Rault M, Costagliola G, Mazzia C (2005) Lethal and sublethal effects of imidacloprid on two earthworm species (Aporrectodea nocturna and Allolobophora icterica). Biol Fertil Soils 41:135-143. doi:10.1007/s00374-004-0829-0

Capowiez Y, Bastardie F, Costagliola G (2006) Sublethal effects of imidacloprid on the burrowing behaviour of two earthworm species: modifications of the 3D burrow systems in artificial soil cores and consequences on gas diffusion in soil. Soil Biol Biochem 38:285-293. doi:10.1016/j.soilbio.2005.05.014

Capowiez Y, Dittbrenner N, Rault M, Hedde M, Triebskorn R, Mazzia C (2010) Earthworm cast production as a new behavioural biomarker for toxicity testing. Environ Pollut 158:388-393. doi:10.1016/j.envpol.2009.09.003

Casabé N, Piola L, Fuchs J, Oneto ML, Pamparato L, Basack S, Gimenez R, Massaro R, Papa JC, Kesten E (2007) Ecotoxicological assessment of the effects of glyphosate and chlorpyrifos in an Argentine soya field. J Soil Sed 7:232-239. doi:10.1065/jss2007.04.224

Casida JE, Quistad GB (1998) Golden age of insecticide research: past, present, or future? Annu Rev Entomol 43:1-16. doi:10.1146/ annurev.ento.43.1.1

Cathey B (1982) Comparative toxicities of 5 insecticides to the earthworm, Lumbricus-terrestris. Agr Environ 7:73-81. doi:10.1016/ j.ecoenv.2011.12.016

Chan KY (2001) An overview of some tillage impacts on earthworm population abundance and diversity - implications for functioning in soils. Soil Tillage Res 57:179-191. doi:10.1016/S01671987(00)00173-2

Choo LPD, Baker GH (1998) Influence of four commonly used pesticides on the survival, growth, and reproduction of the earthworm Aporrectodea trapezoides (Lumbricidae). Aust J Agr Res 49:1297-1303. doi:10.1071/A98021

Christensen OM, Mather JG (2004) Pesticide-induced surface migration by lumbricid earthworms in grassland: life-stage and species differences. Ecotox Env Saf 57:89-99. doi:10.1016/ j.ecoenv.2003.08.007 
Cluzeau D, Lagarde R, Fayolle L (1990) Approche démographique d'une population de Lumbricus terrestris, en liaison avec des apports agropharmaceutiques utilisés en polyculture-élevage, Relations entre les traitements phytosanitaires et la reproduction des animaux. In: ANPP (Ed.), Coll. Int. France 25-26/04/1990, Mucchi, Modena

Collange B, Wheelock CE, Rault M, Mazzia C, Capowiez Y, SanchezHernandez JC (2010) Inhibition, recovery and oxime-induced reactivation of muscle esterases following chlorpyrifos exposure in the earthworm Lumbricus terrestris. Environ Pollut 158:22662272. doi:10.1016/j.envpol.2010.02.009

Correia FV, Moreira JC (2010) Effects of glyphosate and 2,4-D on earthworms (Eisenia foetida) in laboratory tests. Bull Environ Contam Toxicol 85:264-268. doi:10.1007/s00128-010-0089-7

Cortet J, Gomot-De Vauflery A, Poinsot-Balaguer N, Gomot L, Texier C, Cluzeau D (1999) The use of invertebrate soil fauna in monitoring pollutant effects. Eur J Soil Biol 35:115-134. doi:10.1016/ S1164-5563(00)00116-3

Culy MD, Berry EC (1995) Toxicity of soil-applied granular insecticides to earthworm populations in cornfields. Down to Earth 50:20-25

Dalby PR, Baker GH, Smith SE (1995) Glyphosate, 2,4-DB and dimethoate: effects on earthworm survival and growth. Soil Biol Biochem 27:1661-1662. doi:10.1016/0038-0717(95)00091-R

Davis BNK (1971) Laboratory studies on the uptake of dieldrin and DDT by earthworms. Soil Biol Biochem 3:221-233

De Silva PMCS, Pathiratne A, van Gestel CAM (2009) Influence of temperature and soil type on the toxicity of three pesticides to Eisenia andrei. Chemosphere 76:1410-1415. doi:10.1016/ j.chemosphere.2009.06.006

De Silva PMCS, Pathiratne A, van Gestel CAM (2010) Toxicity of chlorpyrifos, carbofuran, mancozeb and their formulations to the tropical earthworm Perionyx excavatus. Appl Soil Ecol 44:56-60. doi:10.1016/j.apsoil.2009.09.005

de Sousa AP, de Andréa MM (2011) Earthworm (Eisenia andrei) avoidance of soils treated with cypermethrin. Sensors 11:1105611063. doi:10.3390/s 111211056

Decaëns T, Margerie P, Aubert M, Hedde M, Bureau F (2008) Assembly rules within earthworm communities in NorthWestern France - a regional analysis. Appl Soil Ecol 39:321335. doi:10.1016/j.apsoil.2008.01.007

Denoyelle R, Rault M, Mazzia C, Mascle O, Capowiez Y (2007) Cholinesterase activity as a biomarker of pesticide exposure in Allolobophora chlorotica earthworms living in apple orchards under different management strategies. Environ Toxicol Chem 26:2644-2649. doi:10.1897/06-355.1

Dittbrenner N, Triebskorn R, Moser I, Capowiez Y (2010) Physiological and behavioural effects of imidacloprid on two ecologically relevant earthworm species (Lumbricus terrestris and Aporrectodea caliginosa). Ecotoxicology 19:1567-1573. doi:10.1007/s10646-010-0542-8

Dittbrenner N, Moser I, Triebskorn R, Capowiez Y (2011) Assessment of short and long-term effects of imidacloprid on the burrowing behaviour of two earthworm species (Aporrectodea caliginosa and Lumbricus terrestris) by using 2D and 3D post-exposure techniques. Chemosphere 84:1349-1355. doi:10.1016/ j.chemosphere.2011.05.011

Dittbrenner N, Capowiez Y, Köhler HR, Triebskorn R (2012) Stress protein response (Hsp70) and avoidance behaviour in Eisenia fetida, Aporrectodea caliginosa and Lumbricus terrestris when exposed to imidacloprid. J Soils Sediments 12:198-206. doi:10.1007/s11368-011-0437-1

Doving KB (1991) Assessment of animal behaviour as a method to indicate environmental toxicity. Comp Biochem Physiol C 100:247-252

Edwards CA (1983) Earthworm ecology in cultivated soils. In: Satchell JE (ed) Earthworm ecology - from Darwin to vermiculture. Chapman \& Hall, London, pp 123-137
Edwards CA, Bohlen PJ (1996) Biology and ecology of earthworms, 3rd edn. Chapman \& Hall, London

Ellis SR, Hodson ME, Wege P (2010) The soil-dwelling earthworm Allolobophora chlorotica modifies its burrowing behaviour in response to carbendazim applications. Ecotox Environ Saf 73:1424-1428. doi:10.1016/j.ecoenv.2010.05.010

Eltun R., Korsæth A, Nordheim O (2002) A comparison of environmental, soil fertility, yield, and economical effects in six cropping systems based on an 8-year experiment in Norway. Agr Ecosyst Environ 90: 155-168. doi: org/10.1016/S0167-8809(01)00198-0

Evans AC (1947) A method for studying the burrowing activities of earthworms. Ann Mag Nat Hist 11:643-650. doi:10.1080/ 00222934708654673

Förster B, Eder M, Morgan E, Knacker T (1996) A microcosm study of the effects of chemical stress, earthworms and microorganims and their interaction upon litter decomposition. Eur J Soil Biol 32:25-33

Fragoso C, Brown GG, Patron JC, Blanchart E, Lavelle P, Pashanasi B, Senapati B, Kumar T (1997) Agricultural intensification, soil biodiversity and agroecosystem function in the tropics: the role of earthworms. Appl Soil Ecol 6:17-35. doi:10.1016/S09291393(96)00154-0\#sthash.SZ4SVAS0.dpuf

Frampton GK, Jänsch S, Scott-Fordsmand JJ, Römbke J, van den Brink PJ (2006) Effects of pesticides on soil invertebrates in laboratory studies: a review and analysis using species sensitivity distributions. Environ Toxicol Chem 25:2480-2489. doi:10.1897/ 05-438R.1

Fründ HC, Butt K, Capowiez Y, Eisenhauer N, Emmerling C, Ernst G, Potthoff M, Schädler M, Schrader S (2010) Using earthworms as model organisms in the laboratory: recommendations for experimental implementations. Pedobiol 53:119-125. doi:10.1016/ j.pedobi.2009.07.002

Gambi N, Pasteris A, Fabbri E (2007) Acetylcholinesterase activity in the earthworm Eisenia andrei at different conditions of carbaryl exposure. Comp Biochem Physiol C- Toxicol Pharmacol 145:678-685. doi:10.1016/j.cbpc.2007.03.002

Gao Y, Sun X, Sun Z, Zhao N, Li Y (2008) Toxic effects of enrofloxacin on growth rate and catalase activity in Eisenia fetida. Environ Toxicol Pharmacol 26:177-180. doi:10.1016/ j.etap.2008.03.004

Garcia M, Römbke J, Torred de Brito M, Scheffczyk A (2008) Effects of three pesticides on the avoidance behavior of earthworms in laboratory tests performed under temperate and tropical conditions. Environ Pollut 153:450-456. doi:10.1016/j.envpol.2007.08.007

Gibbs MH, Wicker LF, Stewart AJ (1996) A method for assessing sublethal effects of contaminants in soils to the earthworm, Eisenia foetida. Environ Toxicol Chem 15:360-368. doi:10.1002/etc.5620150321

Gomez-Eyles JL, Svendsen C, Lister L, Martin H, Hodson ME, Spurgeon DJ (2009) Measuring and modeling mixture toxicity of imidacloprid and thiacloprid on Caenorhabditis elegans and Eisenia fetida. Ecotoxicol Environ Saf 72:71-79. doi:10.1016/ j.ecoenv.2008.07.006

Greig-Smith PW (1992) Recommendations of an international workshop on ecotoxicology of earthworms. In: Greig-Smith PW, Becker H, Edwards PJ, Heimbach F (eds) Ecotoxicology of earthworms. Intercept Ltd, Andover, pp 247-262

Hackenberger BK, Jarić-Perkušić D, Stepić S (2008) Effect of temephos on cholinesterase activity in the earthworm Eisenia fetida (Oligochaeta, Lumbricidae). Ecotoxicol Environ Saf 71:583-589. doi:10.1016/j.ecoenv.2007.11.008

Hedde M, van Oort F, Lamy I (2012) Functional traits of soil invertebrates as indicators for exposure to soil disturbance. Envir Pollut 164:59-65. doi:10.1016/j.envpol.2012.01.017

Hedges LV, Gurevitch J, Curtis PS (1999) The meta-analysis of response ratios in experimental ecology. Ecology 80:1150-1156. doi:10.2307/177062 
Heimbach F (1984) Correlations between three methods for determining the toxicity of chemicals to earthworms. Pestic Sci 15:605611. doi:10.1002/ps.2780150612

Heimbach F (1992) Correlation between data from laboratory and field-tests for investigation the toxicity of pesticides to earthworms. Soil Biol Biochem 24:1749-1753. doi:10.1016/00380717(92)90182-W

Högger CH, Ammon HU (1994) Testing the toxicity of pesticides to earthworms in laboratory and field tests. Bulletin OILB/SROP $17: 157-178$

Hole DG, Perkins AJ, Wilson JD, Alexander IH, Grice PV, Evans AD (2005) Does organic farming benefit biodiversity? Biol Conservat 122:113-130. doi:10.1016/j.biocon.2004.07.018

Holmstrup M (2000) Field assessment of toxic effects on reproduction in the earthworms Aporrectodea longa and Aporrectodea rosea. Environ Toxicol Chem 19:1781-1787. doi:10.1002/ etc. 5620190711

Hutcheon A, Iles DR, Kendall DA (2001) Earthworm populations in conventional and integrated farming systems in the LIFE Project (SW England) in 1990-2000. Annals Appl Biol 139:361-372. doi:10.1111/j.1744-7348.2001.tb00150.x

Iglesias J, Castillejo J, Castro R (2003) The effects of repeated applications of the molluscicide metaldehyde and the biocontrol nematode Phasmarhabditis hermaphrodita on molluscs, earthworms, nematodes, acarids and collembolans: a two-year study in northwest Spain. Pest Manag Sci 59:1217-1224. doi:10.1002/ps.758

Irmler U (2010) Changes in earthworm populations during conversion from conventional to organic farming. Agr Ecosyst Environ 135:194-198. doi:10.1016/j.agee.2009.09.008

ISO (International Organization for Standardization) 17512-1 (2008) Soil quality - avoidance test for determining the quality of soils and effects of chemicals on behaviour-part 1: test with earthworms (Eisenia fetida and Eisenia andrei)

ISO (International Organization for Standardization) (1993) Effects of pollutants on earthworms (Eisenia fetida). Part 1: determination of acute toxicity using artificial soil substrate- No. 11268-1. Geneva

ISO (International Organization for Standardization) (1998) Effects of pollutants on earthworms (Eisenia fetida). Part 2: determination of effects on reproduction-No. 11268-2. Geneva

ISO (International Organization for Standardization) (2004) Soil quality - Avoidance test for testing the quality of soils and the toxicity of chemicals - Test with earthworms (Eisenia fetida) - No. N 281. Geneva

Jänsch S, Frampton GK, Römbke J, van den Brink PJ, ScottFordsmand JJ (2006) Effects of pesticides on soil invertebrates in model ecosystem and field studies: a review and comparison with laboratory toxicity data. Environ Toxicol Chem 25:2490 2501. doi:10.1897/05-439R.1

Jones CG, Lawton JH, Shachak M (1994) Organisms as ecosystem engineers. Oikos 69:373-386. doi:10.2307/3545850

Jordaan MS, Reinecke SA, Reinecke AJ (2012) Acute and sublethal effects of sequential exposure to the pesticide azinphos-methyl on juvenile earthworms (Eisenia andrei). Ecotoxicology 21:649661. doi:10.1007/s10646-011-0821-z

Kautenburger R (2006) Impact of different agricultural practices on the genetic structure of Lumbricus terrestris, Arion lusitanicus and Microtus arvalis. Anim Biodivers Conserv 29:19-32

Keogh RG, Whitehead PH (1975) Observations on some effects of pasture spraying with benomyl and carbendazim on earthworm activity and litter removal from pasture. New Zeal J Exp Agr 3:103-104. doi:10.1080/03015521.1975.10425783

Klobučar GIV, Štambuk A, Šrut M, Husnjak I, Merkaš M, Traven L, Cvetković Z (2011) Aporrectodea caliginosa, a suitable earthworm species for field based genotoxicity assessment? Environ Pollut 159:841-849. doi:10.1016/j.envpol.2011.01.009
Kokta C (1992a) Measuring effects of chemicals in the laboratoryeffect criteria and endpoints. In: Greig-Smith PW, Becker H, Edwards PJ, Heimbach F (eds) Ecotoxicology of earthworms. Intercept, London, pp 55-62

Kokta C (1992b) A laboratory test on sublethal effects of pesticides on Eisenia fetida. In: Greig-Smith PW, Becker H, Edwards PJ, Heimbach $\mathrm{F}$ (eds) Ecotoxicology of earthworms. Intercept, London, pp 213-216

Kreutzweiser DP, Good KP, Chartrand DT, Scarr TA, Holmes SB, Thompson DG (2008) Effects on litter-dwelling and microbial decomposition of soil-applied imidacloprid for control of woodboring insects. Pest Manag Sci 64:112-118. doi:10.1002/ps.1478

Kula H, Larink O (1997) Development and standardization of test methods for prediction of sublethal effects of chemicals on earthworms. Soil Biol Biochem 29:635-639. doi:10.1016/S00380717(96)00030-2

LaCourse EJ, Hernandez-Viadel M, Jefferies JR, Svendsen C, Spurgeon DJ, Barrett J, Morgan AJ, Kille P, Brophy PM (2009) Glutathione transferase (GST) as a candidate molecular-based biomarker for soil toxin exposure in the earthworm Lumbricus rubellus. Environ Pollut 157:2459-2469. doi:10.1016/j.envpol.2009.03.015

Lagadic L, Caquet T, Ramade F (1994) The role of biomarkers in environmental assessment (5). Invertebrate populations and communities. Ecotoxicology 3:193-208. doi:10.1007/BF00117084

Lal OP, Palta RK, Srivastava YNS (2001) Impact of imidacloprid and carbofuran on earthworm casting in Okra field. Ann Plant Protect Sci 9:137-138

Lavelle P, Spain AV (2001) Soil ecology. Kluwer Scientific, Amsterdam

Lavelle P, Decaëns T, Aubert M, Barot S, Blouin M, Bureau F, Margerie P, Mora P, Rossi J-P (2006) Soil invertebrates and ecosystem services. Eur J Soil Biol 42:S3-S15. doi:10.1016/ j.ejsobi.2006.10.002

Lee KE (1985) Earthworms: their ecology and relationship with soils and land use. Academic, New York

Lee KE, Foster RC (1991) Soil fauna and soil structure. Aust J Soil Res 29:745-775. doi:10.1071/SR9910745

Liang J, Zhou Q (2003) Single and binary-combined toxicity of methamidophos, acetochlor and copper acting on earthworms Esisenia foelide. Bull Environ Contam Toxicol 71:1158-1166. doi:10.1007/s00128-003-0228-5

Loureiro S, Soares AMVM, Nogueira AJA (2005) Terrestrial avoidance behaviour tests as screening tool to assess soil contamination. Environ Pollut 138:121-131. doi:10.1016/j.envpol.2005.02.013

Lowe CN, Butt KR (2005) Culture techniques for soil dwelling earthworms: a review. Pedobiol 49:401-413. doi:10.1016/ j.pedobi.2005.04.005

Lowe CN, Butt KR (2007) Earthworm culture, maintenance and species selection in chronic ecotoxicological studies: a critical review. Eur J Soil Biol 43:S281-S288. doi:10.1016/ j.ejsobi.2007.08.028

Luo Y, Zang Y, Zhong Y, Kong Z (1999) Toxicological study of two novel pesticides on earthworm Eisenia foetida. Chemosphere 39:2347-2356. doi:10.1016/S0045-6535(99)00142-3

Ma WC, Bodt J (1993) Differences in toxicity of the insecticide chlorpyrifos to 6 species of earthworms (Oligochaeta, Lumbricidae) in standardized soil tests. Bull Environ Contam Toxicol 50:864-870

Mangala P, de Silva CS, van Gestel CAM (2009) Comparative sensitivity of Eisenia andrei and Perionyx excavatus in earthworm avoidance tests using two soil types in the tropics. Chemosphere 77:1609-1613. doi:10.1016/j.chemosphere.2009.09.034

Marinissen JCY (1992) Population-dynamics of earthworms in a silt loam soil under conventional and integrated arable farming during two years with different weather patterns. Soil Biol Bioch 24:1647-1654. doi:10.1016/0038-0717(92)90164-S 
Martikainen E (1996) Toxicity of dimethoate to some soil animal species in different soil types. Ecotox Environ Saf 3:128-136. doi:10.1006/eesa.1996.0016

Martin NA (1982) The effects of herbicides used on asparagus on the growth rate of the earthworm Allolobophora caliginosa. In: Proceedings of the 35th New Zealand Weed and Pest Control Conference, Palmerston North New Zealand, pp. 328-331

Martin NA (1986) Toxicity of pesticides to Allolobophora caliginosa (Oligochaeta, Lumbricidae). New Zeal J Agr Res 29:699-706

Meysman FJR, Middelburg JJ, Heip CHR (2006) Bioturbation: a fresh look at Darwin's last idea. Trends Ecol Evol 21:688-695. doi:10.1016/j.tree.2006.08.002

Morgan AJ, Kille P, Sturzenbaum SR (2007) Microevolution and ecotoxicology of metals in invertebrates. Environ Sci Tech 41:1085-1096. doi:10.1021/es061992x

Mosleh YY, Paris-Palacios S, Couderchet M, Vernet G (2003a) Effects of the herbicide isoproturon on survival, growth rate, and protein content of mature earthworms (Lumbricus terrestris L.) and its fate in the soil. Appl Soil Ecol 23:69-77. doi:10.1016/S09291393(02)00161-0

Mosleh YY, Ismail SMM, Ahmed MT, Ahmed YM (2003b) Comparative toxicity and biochemical responses of certain pesticides to the mature earthworm Aporrectodea caliginosa under laboratory conditions. Environ Toxicol 18:338-346. doi:10.1002/tox.10134

Mosquera I, Côté IM, Jennings S, Reynolds JD (2000) Conservation benefits of marine reserves for fish populations. Anim Conserv $4: 321-332$

Muthukaruppan G, Paramasamy G (2010) Effect of butachlor herbicide on earthworm Eisenia fetida - its histological perspicuity. Appl Environ Soil Sci. doi:10.1155/2010/850758

Nahmani J, Hodson ME, Black S (2007a) Effects of metals on life cycle parameters of the earthworm Eisenia fetida exposed to fieldcontaminated, metal-polluted soils. Environ Pollut 149:44-58. doi:10.1016/j.envpol.2006.12.018

Nahmani J, Hodson ME, Black S (2007b) A review of studies performed to assess metal uptake by earthworms. Environ Pollut 145:402-424. doi:10.1016/j.envpol.2006.04.009

Neuhauser EF, Callahan CA (1990) Growth and reproduction of the earthworm Eisenia fetida exposed to sublethal concentrations of organic chemicals. Soil Biol Biochem 22:175-179. doi:10.1016/ 0038-0717(90)90083-C

Neuhauser EF, Loehr RC, Malecki MR, Milligan DL, Durkin PR (1985) The toxicity of selected organic-chemicals to the earthworm Eisenia fetida. J Environ Qual 14:383-388

Neuhauser EF, Durkin PR, Malecki MR, Anatra M (1986) Comparative toxicity of 10 organic-chemicals to 4 earthworm species. Comp Biochem Physiol C-Pharmacol Toxicol Endocrinol 83:197-200. doi:10.1016/0742-8413(86)90036-8

Odum HT (1982) Pulsing, power, and hierarchy. In: Mitsch WJ, Ragade RK, Bosserman RW, Dillon JJA (eds) Energetics and systems. Ann Arbor Science Publishing, Ann Arbor, pp 33-60

OECD (1984) Guideline for the testing of chemicals. No. 207. Earthworm, acute toxicity tests. OECD Publishing, Paris

OECD (2001) OECD guidelines for the testing of chemicals/section 1: physical-chemical properties test no. 121: estimation of the adsorption coefficient $\left(K_{\mathrm{oc}}\right)$ on soil and on sewage sludge using high performance liquid chromatography (HPLC). OECD Publishing, Paris

Olvera-Velona A, Capowiez Y, Mascle O, Ortiz-Hernandez L, Benoit P (2008) Assessment of the toxicity of ethyl-parathion to earthworms (Aporrectodea caliginosa) using behavioural, physiological and biochemical markers. Appl Soil Ecol 40:476-483. doi:10.1016/j.apsoil.2008.07.002

Paoletti MG (1999) The role of earthworms for assessment of sustainability and as bioindicators. Agr Ecosyst Environ 74:137-155. doi:10.1016/S0167-8809(99)00034-1
Pauwels M, Frérot H, Souleman D, Vandenbulcke F (2013) Using biomarkers in an evolutionary context: lessons from the analysis of biological responses of oligochaete annelids to metal exposure. Environ Pollut in press

Pelosi C, Bertrand M, Roger-Estrade J (2009a) Earthworm community in conventional, organic and no-tilled with living mulch cropping systems. Agron Sustain Dev 29:287-295. doi:10.1051/agro/2008069

Pelosi C, Bertrand M, Capowiez Y, Boizard H, Roger-Estrade J (2009b) Earthworm collection from agricultural fields: Comparisons of selected expellants in presence/absence of hand-sorting. Eur J Soil Biol 45:176-183. doi:10.1016/j.ejsobi.2008.09.013

Pelosi C, Joimel S, Makowski D (2013) Searching for a more sensitive earthworm species to be used in pesticide homologation tests-a meta-analysis. Chemosphere 90:895-900. doi:10.1016/ j.chemosphere.2012.09.034

Perreira JL, Antunes SC, Ferreira AC, Gonvalces F, Pereira R (2010) Avoidance behavior of earthworms under exposure to pesticides: is it chemosensorial? J Env Sci Health B 45:229-232. doi:10.1080/03601231003613625

Piearce TG, Langdon CJ, Meharg AA, Semple KT (2002) Yellow earthworms: distinctive pigmentation associated with arsenicand copper-tolerance in Lumbricus rubellus. Soil Biol Biochem 34:1833-1838. doi:10.1016/S0038-0717(02)00176-1

Pierret A, Capowiez Y, Belzunces L, Moran CJ (2002) 3D reconstruction and quantification of macropores using $\mathrm{X}$-ray computed tomography and image analysis. Geoderma 106:247-271. doi:10.1016/S0016-7061(01)00127-6

PPDB (2013). http://sitem.herts.ac.uk/aeru/footprint/fr/index.htm

Rault M, Mazzia C, Capowiez Y (2007) Tissue distribution and characterization of cholinesterase activity in six earthworm species. Comp Biochem Physiol B-Biochem Molec Biol 147:340-346. doi:10.1016/j.cbpb.2007.01.022

Reddy MV, Reddy VR (1992) Effects of organochlorine, organophosphorus and carbamate insecticides on the population structure and biomass of earthworms in a semiarid tropical grassland. Soil Biol Biochem 24:1733-1738. doi:10.1016/0038-0717(92)90179-2

Reinecke AJ (1992) A review of ecotoxicological test methods using earthworms. In: Greig-Smith PW, Becker H, Edwards PJ, Heimbach F (eds) Ecotoxicology of earthworms. Intercept, London, pp 7-19

Reinecke AJ, Maboeta MS, Vermeulen LA, Reinecke SA (2002) Assessment of lead nitrate and mancozeb tocivity in earthworm using the avoidance response. Bull Environ Contam Toxicol 68:779-786. doi:10.1007/s00128-002-0023-8

Reinecke AJ, Albertus RMC, Reinecke SA (2008) The effects of organic and conventional management practices on feeding activity of soil organism in vineyards. Afr Zool 43:66-74. doi: 10.3377/1562-7020(2008)43[66:TEOOAC]2.0.CO;2

Ricketts HJ, Morgan AJ, Spurgeon DJ, Kille P (2004) Measurement of annetocin gene expression: a new reproductive biomarker in earthworm ecotoxicology. Ecotoxicol Environ Saf 57:4-10. doi:10.1016/j.ecoenv.2003.08.008

Roark JH, Dale JL (1979) The effect of turf fungicides on earthworms. Ark Acad Sci Proc 33:71-74

Roberts BL, Dorough HW (1985) Hazards of chemicals to earthworms. Environ Toxicol Chem 4:307-323. doi:10.1002/etc.5620040306

Rodriguez-Castellanos L, Sanchez-Hernandez C (2007) Earthworm bioamarkers of pesticide contamination: current status and perspectives. J Pestic Sci 32:360-371. doi:10.1584/jpestics.R07-14

Römbke J, Van Gestel CAM, Jones SE, Koolhaas JE, Rodrigues JML, Moser T (2004) Ring-testing and field-validation of a terrestrial model ecosystem (TME) - an instrument for testing potentially harmful substances: effects of carbendazim on earthworms. Ecotox 13:105-118. doi:10.1023/B:ECTX.0000012408.58017.08

Ruppel HF, Laughlin CW (1977) Toxicity of soil pesticides to earthworms. J Kans Entomol Soc 50:113-118 
Sanchez-Hernandez JC (2006) Earthworm biomarkers in ecological risk assessment. Rev Environ Contam Toxicol 188:85-126. doi:10.1007/978-0-387-32964-2 3

Sanchez-Hernandez JC, Wheelock CE (2009) Tissue distribution, isozyme abundance and sensitivity to chlorpyrifos-oxon of carboxylesterases in the earthworm Lumbricus terrestris. Environ Pollut 157:264-272. doi:10.1016/j.envpol.2008.06.041

Schreck E, Geret F, Gontier L, Treilhou M (2008) Neurotoxic effect and metabolic responses induced by a mixture of six pesticides on the earthworm Aporrectodea caliginosa nocturna. Chemosphere 71:1832-1839. doi:10.1016/j.chemosphere.2008.02.003

Schreck E, Gontier L, Duma C, Geret F (2012) Ecological and physiological effects of soil management practices on earthworm communities in French vineyards. Eur J Soil Biol 52:8-15. doi:10.1016/j.ejsobi.2012.05.002

Scullion J, Neale S, Philipps L (2002) Comparisons of earthworm populations and cast properties in conventional and organic arable rotations. Soil Use and Manag 18:293-300. doi:10.1111/j.14752743.2002.tb00271.x

Scullion J, Neale S, Philips L (2007) Earthworm casting and burrowing activity in conventional and organic grass-arable rotations. Eur J Soil Biol 43:S216-S221. doi:10.1016/j.ejsobi.2007.08.018

Seeber J, Seeber GUH, Kössler W, Langel R, Scheu S, Meyer E (2005) Abundance and trophic structure of macro-decomposers on alpine pastureland (Central Alps, Tyrol): effects of abandonment of pasturing. Pedobiol 49:221-228. doi:10.1016/j.pedobi.2004.10.003

Siegrist S, Schaub D, Pfiffner L, Mäder P (1998) Does organic agriculture reduce soil erodibility? The results of a long-term field study on loess in Switzerland. Agr Ecosyst Environ 69:253-264. doi:10.1016/S0167-8809(98)00113-3

Sims RW, Gerard BM (1999) Earthworms. FSC Publications, London

Slimak KM (1997) Avoidance response as a sublethal effect of pesticides on Lumbricus terrestris (Oligochaeta). Soil Biol Biochem 29:713-715. doi:10.1016/S0038-0717(96)00027-2

Springett JA, Gray RAJ (1992) Effect of repeated low-doses of biocides on the earthworm Aporrectodea caliginosa in laboratory culture. Soil Biol Biochem 24:1739-1744. doi:10.1016/0038-0717(92)90180-6

Spurgeon DJ, Hopkin SP (1996) The effects of metal contamination on earthworm populations around a smelting works - quantifying species effects. Appl Soil Ecol 4:147-160. doi:10.1016/09291393(96)00109-6

Spurgeon DJ, Weeks JM, Van Gestel CAM (2003) A summary of eleven years progress in earthworm ecotoxicology. Pedobiol 47:588-606. doi:10.1078/0031-4056-00234

Stringer A, Wright MA (1976) The toxicity of Benomyl and some related 2-substituted benzimidazoles to earthworm Lumbricus terrestris. Pestic Sci 7:459-464. doi:10.1002/ps.2780070507

Svendsen C, Weeks JM (1997) A simple low-cost field mesocosm for ecotoxicological studies on earthworms. Comp Biochem Physiol CPharmacol Toxicol Endocrinol 117:31-40. doi:10.1016/S07428413(97)85596-X

Svendsen C, Spurgeon DJ, Hankard PK, Weeks JM (2004) A review of lysosomal membrane stability measured by neutral red retention: Is it a workable earthworm biomarker? Ecotoxicol Environ Saf 57:20-29. doi:10.1016/j.ecoenv.2003.08.009

Svendsen TS, Hansen PE, Sommer C, Martinussen T, Gronvold J, Holter P (2005) Life history characteristics of Lumbricus terrestris and effects of the veterinary antiparasitic compounds ivermectin and fenbendazole. Soil Biol Biochem 37:927-936. doi:10.1016/j.soilbio.2004.10.014

Svendsen C, Owen J, Kille P, Wren J, Jonker MJ, Headley BA, Morgan AJ, Blaxter M, Stürzenbaum SR, Hankard PK, Lister LJ, Spurgeon DJ (2008) Comparative transcriptomic responses to chronic cadmium, fluoranthene, and atrazine exposure in Lumbricus rubellus. Environ Sci Tech 42:4208-4214. doi:10.1021/es702745d
Tarrant KA, Field SA, Langton SD, Hart ADM (1997) Effects on earthworm populations of reducing pesticide use in arable crop rotations. Soil Biol Biochem 29:657-661. doi:10.1016/S00380717(96)00191-5

Tomlin AD (1992) Behaviour as a source of earthworm susceptibility to ecotoxicants. In: Greig-Smith PW, Becker H, Edwards PJ, Heimbach F (eds) Ecotoxicology of earthworms. Intercept, Andover, pp 116-125

Tu C, Wang Y, Duan W, Hertl P, Tradway L, Brandenburg R, Lee D, Snell M, Hu S (2011) Effects of fungicides and insecticides on feeding behavior and community dynamics of earthworms: Implications for casting control in turfgrass systems. Appl Soil Ecol 47:31-36. doi:10.1016/j.apsoil.2010.11.002

van Gestel CAM (1992a) Validation of earthworm toxicity tests by comparison with field studies: a review of benomyl, carbendazim, carbofuran, and carbaryl. Ecotoxicol Environ Saf 23:221-236. doi:10.1016/0147-6513(92)90060-G

van Gestel CAM (1992b) The influence of soil characteristics on the toxicity of chemicals for earthworms: a review. In: Greig-Smith PW, Becker H, Edwards PJ, Heimbach F (eds) Ecotoxicology of earthworms. Intercept, London, pp 44-54

van Gestel CAM, van Dis WA (1988) The influence of soil characteristics on the toxicity of four chemicals to the earthworm Eisenia fetida andrei (Oligochaeta). Biol Fertil Soils 6:262-265. doi:10.1007/BF00260822

van Gestel CAM, van Brummelen TC (1996) Incorporation of the biomarker concept in ecotoxicology calls for a redefinition of terms. Ecotoxicology 5:217-225. doi:10.1007/BF00118992

van Gestel CAM, Weeks JM (2004) Recommendations of the 3rd International Workshop on Earthworm Ecotoxicology, Aarhus, Denmark, August 2001. Ecotoxicol Environ Saf 57:100-105

van Gestel CAM, van Breemen EM, Baerselman R, Emans HJB, Janssen JAM, Postuma R, van Vliet PJM (1992) Comparison of sublethal and lethal criteria for nine different chemicals in standardized toxicity tests using the earthworm Eisenia andrei. Ecotoxicol Environ Saf 23:206-220. doi:10.1016/0147-6513(92)90059-C

van Gestel CAM, Kruidenier M, Berg MB (2003) Suitability of wheat straw decomposition, cotton strip degradation and bait-lamina feeding tests to determine soil invertebrate activity. Biol Fertil Soils 37:115-123. doi:10.1007/s00374-002-0575-0

Venkateswara Rao J, Surya Pavan Y, Madhavendra SS (2003) Toxic effects of chlorpyrifos on morphology and acetylcholinesterase activity in the earthworm, Eisenia foetida. Ecotoxicol Environ Saf 54:296-301. doi:10.1016/S0147-6513(02)00013-1

Venter JM, Reinecke AJ (1987) Effects of the pesticide dieldrin on incubation of the earthworm Eisenia fetida (Oligochaeta). S Afr J Zool 22:97-100

Vermeulen LA, Reinecke AJ, Reinecke SA (2001) Evaluation of the fungicide manganese-zinc ethylene bis(dithiocarbamate) (mancozeb) for sublethal and acute toxicity to Eisenia fetida (Oligochaeta). Ecotoxicol Environ Saf 48:183-189. doi:10.1006/ eesa.2000.2008

Viswanathan R (1997) Physiological basis in the assessment of ecotoxicity of pesticides to soil organisms. Chemosphere 35:323-334. doi:10.1016/S0045-6535(97)00158-6

Wang JH, Zhu LS, Liu W, Wang J, Xie H (2012) Biochemical responses of earthworm (Eisenia foetida) to the pesticides chlorpyrifos and fenvalerate. Toxicology Mechanisms and Methods 22:236-241. doi:10.3109/15376516.2011.640718

Weeks JM (1995) The value of biomarkers for ecological risk assessment: academic toys or legislative tools? Appl Soil Ecol 2:215216. doi:10.1016/0929-1393(95)00072-2

Wright MA (1977) Effects of benomyl and some other systemic fungicides on earthworms. Ann Appl Biol 87:520-524

Wright MA, Stringer A (1973) The toxicity of thiabendazole, benomyl, methyl benzimidazol-2-yl carbamate and thiophanate-methyl to 
the earthworm Lumbricus terrestris. Pestic Sci 4:431-432. doi: $10.1002 /$ ps. 2780040322

Xiao N, Jing B, Ge F, Liu X (2006) The fate of herbicide acetochlor and its toxicity to Eisenia fetida under laboratory conditions. Chemosphere 62:1366-1373. doi:10.1016/ j.chemosphere.2005.07.043

Yasmin S, D'Souza D (2007) Effect of pesticides on the reproductive output of Eisenia fetida. Bull Environ Contam Toxicol 79:529 532. doi:10.1007/s00128-007-9269-5

Yasmin S, D'Souza D (2010) Effects of pesticides on the growth and reproduction of earthworm: a review. Appl Environ Soil Sci Article, doi:10.1155/2010/678360

Zang Y, Zhong Y, Luo Y, Kong ZM (2000) Genotoxicity of two novel pesticides for the earthworm, Eisenia fetida. Environ Pollut 108:271-278. doi:10.1016/S0269-7491(99)00191-8

Zhang QM, Zhu LS, Wang J, Xie H, Wang JH, Han YN, Yang JH (2013) Oxidative stress and lipid peroxidation in the earthworm
Eisenia fetida induced by low doses of fomesafen. Environ Sci Pollut Res 20:201-208. doi:10.1007/s11356-012-0962-5

Zhou QX, Zhang QR, Liang JD (2006) Toxic effects of acetochlor and methamidophos on earthworm Eisenia fetida in phaiozem, northeast China. J Environ Sci 18:741-745

Zhou SP, Duan CQ, Fu H, Chen YH, Wang XH, Yu ZF (2007) Toxicity assessment for chlorpyrifos-contaminated soil with three different earthworm test methods. J Environ Sci 19:854-858. doi:10.1016/ S1001-0742(07)60142-9

Zhou SP, Duan CQ, Wang XH, Michelle WHG, Yu ZF, Fu H (2008) Assessing cypermethrin-contaminated soil with three different earthworm test methods. J Environ Sci 20:1381-1385. doi:10.1016/S1001-0742(08)62236-6

Zhou SP, Duan CQ, Michelle WHG, Yang F, Wang XH (2011) Individual and combined toxic effects of cypermethrin and chlorpyrifos on earthworm. J Environ Sci 23:676-680. doi:10.1016/ S1001-0742(10)60462-7 